\title{
EVALUATING ONTARIO IMMIGRATION DETENTION CENTRES THROUGH THE LENS OF NON-GOVERNMENTAL ORGANIZATIONS
}

by

Sharyne Williams, BA, Wilfrid Laurier University, 2018

\author{
A Major Research Paper \\ Presented to Ryerson University \\ In partial fulfillment of the requirements for the degree of \\ Master of Arts \\ in the program of \\ Immigration and Settlement Studies
}

Toronto, Ontario, Canada, 2019

(C) Sharyne Williams 2019 


\section{AUTHOR'S DECLARATION}

I hereby declare that I am the sole author of this thesis. This is a true copy of the thesis, including any required final revisions, as accepted by my examiners.

I authorize Ryerson University to lend this thesis to other institutions or individuals for the purpose of scholarly research

I further authorize Ryerson University to reproduce this thesis by photocopying or by other means, in total or in part, at the request of other institutions or individuals for the purpose of scholarly research.

I understand that my thesis may be made electronically available to the public.

Sharyne Williams 


\title{
EVALUATING ONTARIO IMMIGRATION DETENTION CENTRES THROUGH THE LENS OF NON-GOVERNMENTAL ORGANIZATIONS
}

\author{
Sharyne Williams \\ Master of Arts 2019 \\ Immigration and Settlement Studies \\ Ryerson University
}

\begin{abstract}
This Masters Research Paper provides a critical analysis of the behavioural practices of immigration detention centres and how that affects the abilities of NGOs to support immigration detainees. This paper aims to identify the covert racism that is embedded within immigration detention centres in Canada, exploring how racialized detainees are susceptible to longer detention periods and mal-treatment due to increasing securitization. There will be focus on Ontario immigration detention centres in particular since many of Canada's asylum claims and detention processes occur in Toronto and the greater Toronto area. This research fills the gap in directly addressing the impacts of racist practices of detention and how it impacts detainees' ability to seek proper legal aid and interferes with NGOs abilities to aid detainees through their detention process. The methodology used begins with a theoretical framework using Critical Race Theory and background content on immigration detention centres, while drawing out the process of the criminalization of refugees. For this study there were one-on-on interviews conducted with 3 participants who are NGO representatives.
\end{abstract}

Key words: immigration detention centre, detainees, national security, criminalization 


\section{ACKNOWLEDGEMENTS}

To begin I would like to thank my QUEEN, my mother, Kurl Williams for her unconditional love and support, and my father, Don Williams for his continuous words of encouragement. A big THANK YOU to my older siblings, Ron Williams, Desirée Williams and Alyshia Williams for always being there for me and being amazing role models in my life. I cannot express the amount love and pride I have for my family.

Thank you to my supervisor Dr. Graham Hudson for the support and encouragement throughout the entire process and believing in my abilities to take on this research study. You have made me a better researcher and academic throughout this process. I would also like to thank my second reader Dr. Idil Atak for her critiques and insightful contributions to the final production of my MRP.

A final and deserved salute to the 2018-2019 cohort for making it through the year and creating the best support system a colleague could ask for, I am grateful for every one of you. We did it!!!

Thank you to my friends Sinthu Vimaladasan, Paige Edwards-Grant, Constance Bowen, Jamaal Owusu-Ansah and Sierra Lianga, without the five of you I do not know what I would do! Thank you for your continuous support, kind words, listening ears and strong shoulders. I am lucky to have such amazing, forward-thinking friends in my life.

A special thank you to my number one supporter Favour Alaghodaho. Thank you for standing beside me through all the ups and downs throughout this year and encouraging me to continue. You have made a huge contribution to my continued success and I am forever grateful to have you in my life.

Last, but not least, thank you to all the participants in the study, without your contribution this paper could not be possible. Thank you for sharing your stories and allowing myself and the readers to be witness to your experiences. Thank you for your courage and perseverance to create change for the detainee community.

\footnotetext{
"Now that private prison companies have found that they can make a killing on mass incarceration, these private prison companies are now in the business of building detention centers for suspected illegal immigrants" - Michelle Alexander
} 
TABLE OF CONTENTS

AUTHOR'S DECLARATION

II

ABSTRACT III

ACKNOWLEDGEMENTS IV

POSITIONALITY 1

INTRODUCTION 1

METHODOLOGY 4

METHOD OF STUDY 4

RECRUITMENT METHOD 5

SAMPLING 6

INTERVIEW DESIGN 6

ETHICAL CONSIDERATION IN RECRUITMENT 7

ETHICAL CONSIDERATIONS DURING THE INTERVIEW 7

LIMITATIONS OF THE STUDY 8

RESEARCH QUESTION

OVERVIEW OF IMMIGRATION DETENTION CENTRES IN CANADA

LAWS AND REGULATIONS GOVERNING DETENTION

IMMIGRATION HOLDING CENTRES VS PROVINCIAL JAILS

BACKGROUND

THE IMPACTS OF NEOLIBERALISM AND GLOBALIZATION ON MigRATION 
RACE AT PLAY

The Mass Detention of Black and Brown Individuals 40

Addressing the Needs of the Black and Brown Community 41

HEALTH AND WELLNESS OF DETAINEES ____ 43

Unwarranted punishment _______ 44

Deterioration of Mental and Physical Health______ 45

SUPPORT CHALLENGES ___ 46

Procedural Barriers _____ 46

ACTIVISM WITHIN THE COMMUNITY ___ 47

Hunger Strike ___ 48

Phone line ___ 48

Changing the Narrative ____ 48

Recommended Changes to be Made to Uplift the Detainee Community____ 50

DISCUSSION ___ 52

CONCLUSION AND RECOMMENDATIONS

APPENDIX __ 59

CONSENT FORM ___

REFERENCES _ _ _ 62 


\section{POSITIONALITY}

Conducting qualitative research as a graduate student, it is important that I disclose my positioning to the topic at hand. I have an "insider" perspective because I have engaged in activism work to help detainees protect their rights within immigration detention centres. My activism has extended to support released detainees through a detainee support group within Toronto. Additionally, this study remains close to my identity as I am a Black woman attempting to put an end to yet another governmental institution detaining thousands of Black and Brown individuals.

\section{INTRODUCTION}

During Canada's federal elections, politicians use immigration as a political tool to build their platforms. They have constructed migration as a direct threat to Canada's national security, exclaiming that refugees are flooding the border and, hiding among them, are terrorists and criminals (Lacroix, 2004). In the past election in 2015, the current Prime Minister, Justin Trudeau, boldly promised to change this discourse, making Canada a welcoming place for refugees; however, Trudeau failed to address the continuing concerns around migrant detention in Canada, among other issues (Global Detention Project, 2018). The annual report released by the Canadian Border Service Agency (CBSA) demonstrates that, across Canada, immigrants spent 119,712 days in detention in 2017-18 with an average of 14.3 days per person (CBSA, 2018). In 2017-18 an estimated $48 \%$ of all detentions occurred were within Ontario $(4,040)$ (CBSA, 2018). Migrant detention illustrates that Trudeau and other Canadian politicians have not made any meaningful changes to anti-immigration laws, policies, or discourses. This showcases a disconnect between convenient political promises and practice. 
Security and the criminalization of migration are part of the problem. In 2002, Canada put into force the Immigration and Refugee Protection Act (IRPA), which outlines the grounds and regulations for migrant detention. The text of the IRPA includes provisions that characterize irregular migrants as a threat to national security, in part through broad powers of detention on grounds of public safety and security as well as expanded criteria of inadmissibility. National security and criminalization reinforce an $u s v s$. them mentality because it fosters a sense in society there is always an unknown entity that must be feared in which the government protects society from (Amin-Khan, 2015). Since, there is no definitive threat, the "threat" can be construed to what politicians deem to be a threat to the nation at any given moment.

This language contrasts with the 1971 Multiculturalism Act (Arat-Koç, 2005). The Multiculturalism Act represents the three central tenets of the Canada's national identity by (1) recognizing the growing demographic diversity in Canada (2) protecting minorities against institutional discriminations (employment access, education access, access to property, etc.) and (3) integrating minorities in the Canadian identity through embracing institutional celebrations of minority cultures (Kallen, 1982). There are debates about whether the Act made any changes for racialized communities, but it is held as a representation of Canada's commitment to accepting diversity (Kallen, 1982).

Yet, critics argue that dominant Canadian identities remain that of the White European male. This creates socioeconomic disparities for those with marginalized intersectional identities (i.e. those who are not White CisMen). An individual with more intersectional identities is perceived to be further away from the social norm of society and due to their marginalized identities, they are perceived as a threat to the nation state (Potter, 2015). Intersectionality is a term coined by Crenshaw (1991), which describes the way identities (i.e. race, religion, gender, 
class, etc.) intersect to change one's power and privilege in society. Intersectionality

demonstrates how Whiteness functions as a position of power and privilege within society which dominates other identities to achieve upward mobility within society (Potter, 2015). Thus, when politician deem that there is an attack on the Canadian identity or the nation state then they are simply alluding that there is a threat to Whiteness.

Asylum seekers and other irregular migrants are deemed to be the greatest threat due to the way they bypass usual border controls and, often, because they lack the documents needed to prove their identity; if the migrant cannot identify who they are, thy are easily viewed as a threat (Lacroix, 2004). There is also concern that irregular migrants will not appear for hearings and will fall off the radar, living as an undocumented person. The notion of flight risk is often associated with criminality or security: not being able to track their location or actions, the government fears these migrants may engage in criminal acts. Thus, the policies around detention of migrants are preventive in nature and based on the simple possibility of risk and the perceived loss of control, rather than concrete evidence of wrongdoing.

Criminalization and securitization have especially negative consequences on racialized asylum seekers. Migrants that make refugee claims in Toronto have a higher detention rate than any other region in Ontario, at an average of 99 days behind bars, and are detained longer than non-refugee claimant detainees in Toronto (CCR, 2016). More recently CBSA reported that "3.8 per cent of detainees were held for more than 99 days, while 47.2 percent were held for 24 hours or less. The rest were held somewhere between 25-48 hours and 40-99 days" (Canadian Press, 2019, p. 1). Racialized detainees are subject to longer detention periods and mal-treatment throughout the detention process due to Canada's increasing securitization (Amin-Khan, 2015). Asylum seekers are predominantly a racialized demographic which disrupts the historically 
Eurocentric identity of Canada. Consequently, Politicians have pinned migrants as the 'other' in society. There needs to be a process of challenging racism in the immigration system and, in particular, the detention regime (Amin-Khan, 2015).

\section{METHODOLOGY \\ Method of Study}

For this study primary qualitative research was conducted in Ontario, focusing on immigration detention centres and its impact on key stakeholder experiences. The methodological approach used to conduct the research is the phenomenological approach. A phenomenological research study demonstrates the shared lived experience of several individuals of a particular phenomenon (Creswell \& Poth, 2018). Through gathering varying narratives, the phenomenological approach attempts to create a story that details the various experiences of the phenomenon. For the study I have interviewed 3 participants that are Non-Governmental Organization representatives and activists, so as to gather their experiences in relation to immigration detention centres. There is a focus on using critical race theory to deconstruct the use immigration detention centres in relation to the socially constructed notion of race in society. There will be relations made between government institutions and institutional racism, such as detention centres detaining mass amounts of racialized people. Additionally, there is an emphasis on resilience within the detainee community, more specifically against indefinite sentencing that occurs within Canada, since detainees have agency within their environments to create social change. Within the analysis there is a use of direct quotes to share the participants stories to ensure their voices are the ones building the narrative of their experience (Creswell \& Poth, 2018). The study uses the mass detention of racialized bodies in detention centres as a case to note that immigration detention centres are a racist institution (Delgado, 2017). 
Additionally, CRT emphasizes the importance of narrative building and storytelling to share, describe and analyse the experiences of racialized individuals within an institution, which is one of the aims of this study (Delgado, 2017). Immigration detention centres have brought great injustices to the detainee populations and their support systems, however, there are social justice movements that are combating the treatment of detainees and demanding for policy change. This research study will be guided by four leading research questions (1) How do nongovernmental organization perceive their relationship with immigration detention centres? (2) How do professional supporters of detainees perceive their client's treatment within immigration detention centre? (3) How do NGOs perceive racialized detainees' experiences within immigration detention centres? And (4) what are the activist movements that are being done to combat the challenges that detainees are facing? This study was approved by the Ryerson Ethics Board.

\section{Recruitment Method}

Detainees are a highly vulnerable population and difficult population to reach thus I used a third-party list server of organizations that support detainees to send out a notice for participants in the study. These organization were selected based on their known involvement in detainee support campaigns such as, end immigration detention centres, the hunger strike and a detainee phone line. The organization also demonstrated through contact knowing detainees through the services they provide for detainees and their families. To ensure confidentiality a recruitment flyer was sent out with Sharyne Williams contact information, so the participant did not have to notify anyone of their participation. Additionally, I receive consent from the organization to use their list server as a means for contacting detainees to participate within the study. Once contacted for participation the participant was sent a consent form to read over prior 
to the interview, there is no obligation to sign the consent form at this time, but it allows time for the participant to read over the study and risks of participation.

\section{Sampling}

Due to the short study period for three months, as a Master student, I was limited to interviewing 3 participants for the study. Each one of the participants are seen as key informants as they have direct interactions with the institutional processes and barriers of immigration detention centres. Participants were pulled from Non-governmental Organizations, these individuals must identify with an NGO and have or are currently working on movements, campaigns, demonstration in protest of immigration detention centres or are supporting detained and released detainees. The participants were reached through flyer designs sent out via email and through word of mouth.

\section{Interview Design}

Three in-depth semi-structured interviews were conducted and recorded with participants. Participants received their consent forms in advance to read over before entering as a participant (Van den Hoonaard, 2012). In-depth semi-structured interviews are conducted with few openended questions that aim to receive the perspective of the participants experiences (Van den Hoonaard, 2012). Throughout the interview I used prompts for clarification and expansion on the participants stories to ensure a fully completed answer and narrative was delivered (Van den Hoonaard, 2012). Every participant had the right to leave the study at any point during the study and will have their data pulled from the study if requested. Since the participants may not feel comfortable signing documents due to the fragility of the topic there was an option granted to allow participants to give oral consent. When the participant gives oral consent, it was noted down in my notes to be kept for consent references and hand note transcriptions were taking 
throughout the interview. An example of the consent agreement will be found below in the appendix section of my MRP. The questions developed were designed to address types of interactions that NGO participants have with immigration detention centres.

\section{Ethical Consideration in Recruitment}

There was ethical consideration that had to be analyzed prior to starting the study in regard to recruitment because of the sensitivity of the topic. NGOs may be hesitant to share their client's information with me because of the trauma they and or the client may have faced within immigration detention centres and their potential lack of trust towards institutional figures. Thus, creating a safe environment where confidentiality can be upheld for their interviews to take place is a high priority to diminish these risks. Even more, I gave a personal bio to each participant, this way, they are exposed to the researcher they will be sharing their experiences with and can ask any clarification questions about my experience and positionality on the topic. Lastly, NGOs may be constrained through social pressures or ties to what they feel they can or cannot share with me as a participant to mitigate this concern it was made clear to participants via the consent form that all information is kept confidential and their participation in this study will have no impact on their current or future social and administrative ties.

\section{Ethical Considerations During the Interview}

Interviews were conducted in spaces where the participant's identity could not be identified in relation to this study. Additionally, the participant was given time before starting the interview to review the consent form, address any comments or concerns before signing. It was clearly noted in the consent form and prior to the interview that any names mentioned will be changed to a pseudo name and any personal identifiers said within the interview will be taken out for final dissemination or changed if applicable. This ensured confidentiality throughout the 
entire process of the research study. Moreover, after speaking about challenges or adversity the participant was offered to take a break or pause in the interview to allow for emotional monitoring and to lower the possibility of overwhelming the participant with memories or past traumas. Furthermore, former detainees are a vulnerable population and there needed to be great care with ensuring that the participant knows that sharing detainees' experiences was not being exploited for personal or institutional gain.

\section{Limitations of the Study}

The first limitation that must be identified is the lack of time that the research was conducted in and the lack of resources that are available as a graduate student in a one-year master's program. Thus, the sample size will not be large enough to make any substantial conclusion, however, along with larger research studies and existing literature it will add to the body of literature pertaining to immigration detention centres. Additionally, my sample will be missing the perspective of current detainees, former detainees and those who were detained within immigration detention centre and got deported. The status of being deported or being released with conditions could change the detainees experience within immigration detention centres which would need further studying. Although, this is an area that could be analyzed within this work there is not enough resources or time to have that piece of literature added into this particular study. Lastly, since the narratives of detainees are shared via detainee support professionals there could be an issue of strength of memory on details since the participant may have supported detainees who have been released years ago. 


\section{RESEARCH QUESTION}

There are academics that have studied the psychological impacts of migrant detention in other western context such as the UK, Australia and the Unites States (Bosworth \& Turnbull, 2014). This research study aims to capture the effects of immigration detention centres on Nongovernmental Organization (NGOs) in Canada that support and advocate for detainees. This research is guided by three main research questions (1) How do non-governmental organization perceive their relationship with immigration detention centres? (2) How do professional supporters of detainees perceive their client's treatment within immigration detention centre? (3) How do NGOs perceive racialized detainees' experiences within immigration detention centres? And (4) what are the activist movements that are being done to combat the challenges that detainees are facing? Detainees experience extreme marginalization within the Canadian society, nonetheless, detainees have demonstrated various movements of resilience which is discussed further in the paper. The aims of the research in this study is to explore the experience of all noncitizens in detention including, permanent residents, asylum seekers and other migrants.

\section{OVERVIEW OF IMMIGRATION DETENTION CENTRES IN CANADA}

Immigration detention centres are not a new phenomenon; however, Western countries have increasingly used detention centres since the late 1990s (Bosworth \& Turnbull , 2014). Immigration detention centres and provincial jails have been used to monitor and control the influx of migrants coming to the Canadian border. According to CBSA in 2017-18, Canada detained 8,355 people, which was an increase from the 6,268 people detained a year earlier (CBSA, 2018). More than double the amount (53\%) of detainees are held in jails rather than holding centres. It was reported that 1,831 people were detained in provincial jails in 2017-18 while in the previous year CBSA reported 971 in 2016-17 (Canadian Press, 2019). This 
becomes difficult to accept when the statistics demonstrate that the majority of those processed by the CBSA for detention were detained under the grounds of being a flight risk, which was a total of 6,737 persons in 2017-18 (CBSA, 2018). These statistical data points demonstrate that the majority of those who are detained within detention centres are not a risk to the public and solely held for administrative tracking purposes. The detention of migrants in provincial jails is inhumane and unwarranted punishment because they are held in poorly kept spaces that cause mental and physical health deterioration due to their running similarities to correctional facilities (Puthoopparambil, Bjerneld, \& Källestål, 2015).

Immigration detention centres are increasingly becoming comparable to prisons and other correctional facilities, because of its punitive environment (cells, cellmates, guards and facility security monitoring) and the treatment of detainees (Bosworth \& Turnbull, 2014). Bosworth and Turnbull (2014) describe detention centres as "complex and ambiguous, combining elements of hospitality and care with coercion and control" (p. 3). Many detention institutions in Canada, UK, Australia and the US were or are currently correctional facilities, meaning, these buildings are meant for high security grade prisoners to be held in confinement and punished due to their perceived threat to public safety that was assessed by a judge and/or jury (Bosworth \& Turnbull, 2014). The use of former correctional facilities starts to illustrate the blurring of criminal law and immigration policy regarding migrant detention.

Criminologist use the framework of crimmigration to outline and define the impacts of using criminal law on migrants who are not subject to judicial procedure. Crimmingration is the analysis of blurred partnership of immigration law and criminal law which controls immigration practices such as immigration detention reviews and detention centres (Hudson, Nakache, \& Atak, 2018). Administrative policies are what have jurisdictions over immigration applications, 
detention centres, claimant reviews and more. However, even within the jurisdiction of administration policy, there is a prominent use of criminal justice language and systemic functions within the treatment of immigration detainees (Hudson et al., 2018). Immigrants are depicted as a threat to be seen as criminals due to their contrast of the perceived Canadian. Dhamoon and Abu-Laban (2009) identify that the Canadian identity is balancing four categories "that between an indigenous population and settler population; that between whites and nonwhites; that between European groups (French and British origin or French speakers and English speakers); and that between immigrants and native-born.” (p.164) The conflicting identity between the immigrant and native-born depicts the immigrant as the "dangerous internal foreigner' (Dhamoon \& Abu-Laban, 2009). Due to this perceived dangerous identity formed around immigrants' correctional facilities are formed into detention centres to monitor and filter through 'legal' and 'illegal' immigrants (Bosworth \& Turnbull, 2014). Detention centers filters the Canadian immigration system to ensure that only the migrants that the Canadian government deems as deserving are the ones who enter the nation state. The migrants who are not seen as deserving are placed within detention centers and must endure detention policies and practices.

\section{Laws and Regulations Governing Detention}

Immigration detention centre laws are arbitrary and punitive towards immigration detainees. Detention centres are under administrative policy and is governed by the Immigration and Refugee Protection Act (IRPA) which outlines the grounds for detention as well as detention processing (Canadian Government Justice Laws Website, 2018). Migrants can be detained on three main grounds upon making their in land claims, if through the process the migrant is found 1) unable to provide proper identification document, 2) perceived as a flight risk, meaning they will not present themselves at their detention reviews or go underground without completing the 
claims process; or 3) the detainee is viewed a threat to public safety, they will be detained (Canadian Government Justice Laws Website, 2018). Once the detainee falls under one of these grounds for detention, the Canadian Border Service Agency (CBSA) detains the migrant for immigration reasonings. There are also cases where the Minister Council will order a security certificate on a migrant which they will then be detained within 48 hours of the issued certificate (SCC, 2007). Security certificates outline the individual who is to be detained and the reasoning for their detention (SCC, 2007). The information on the certificates was not shared with the detainee since there was a belief that if the individual had access to the information it will lead to a national security threat. This lack of transparency left detainees to feel that their detention sentence was arbitrary and cruel since they were not within their rights to know the details of their own detention sentence. This continued until Charkaoui sued the government for infringing on immigration detainees' rights under the Charter of Rights and Freedom (SCC, 2007). The Supreme Court of Canada (SCC) ruled in favour of Charkaoui stating that security certificates where infringing on section 7 , and 10 of the Charter which suspended the use of security certificates (SCC, 2007).

The suspension was later lifted by the Harper government with an amendment that detainees have a right to a special advocate who will be given the information that is on the security certificate (SCC, 2007). The issue was found that special advocates were not being given the full information that was placed on the certificates and the special advocate has discretion on how much information they shared with the detainee (SCC, 2007). Thus, there were still moments were detainees were not fully informed about their detention.

The guidelines outlined within the IRPA detail that detainees can be detained for a couple days to many years without knowing when they will be released. Once detained the detainee will 
appear before an Immigration Division (ID) member in a Detention Review (Canadian Government Justice Laws Website, 2018). During this review the ID member will make a case as to why the detainee will be deported, be able to stay or if they will continue to be detained. After that initial hearing and it is found that the detainee will continue to be detained, they will not have another review for 7 days, after the 7 days period the detainee will appear once more in an review and if the detainee is still found to continue their detention sentence then they will proceeds with having a detention review every 30 days until a decision is made (Canadian Government Justice Laws Website, 2018). The detention reviews are held with an ID member, the detainee, the immigration lawyer and at times a bonds person, whom is an individual who is stating they will be responsible for the detainee once released. The ID member is asked rigorous questions about the detainees' home country, their identity, friends, family and other domains on their life to gain credibility of knowing the detainee well enough to be granted the right to post bail (Canadian Government Justice Laws Website, 2018). Using the sole discretion of the ID member is unreliable on deeming what qualifies as credible and what is not credible, simply stated the ID members needs to be convinced that the detainee is not lying. There are culturally embedded behavioural acts that need to be considered into how an individual reads the truth (Macklin, 1998). Many cultures treat members of authority differently as well, such as eye contact, many cultures do not make eye contact with elders or respected members in society whereas some culture deem making eye contact a sign of respect and believability (Macklin, 1998). Additionally, everyone carries biases within them for example, if a detainee shows a scar as evidence to them being at risk if they returned to their home country this can be seen as viable evidence or not depending on the ID member experience (Macklin, 1998). If the ID member is someone who was clumsy, grew up receiving scars and bruises, they may not view a scar as a 
strong piece of evidence compared to someone who did not often receive injuries growing up. These minor discretions can lead individuals from coming to different conclusions of allowing someone to stay or be deported. It has been seen in decision making where similar cases will receive different responses because they see different ID members. Even an ID member who hears a similar narrative from two different detainees can come to two different conclusions for the two cases regardless of similarities (Macklin, 1998). Moreover, during detention reviews detainees are not fairly represented as they are not always guaranteed to have an interpreter at their review.

Furthermore, the anti-smuggling legislation Bill C-31, the Protecting Canada's Immigration System Act, implements mandatory detention for all irregular migrants to Canada (Moffette \& Aksin, 2018; Global Detention Project, 2018). The Global Detention Projects states that during the first 12 months of detention there is no judicial review administered to the detainee. Additionally, through Bill C-31 the Minister has complete control over which countries are deemed as safe country and which are deemed unsafe (Moffette \& Aksin, 2018). The concern with having the power in the Minister's control is that migrants who are travelling from a country that is deemed safe by the Minister is unable to appeal the decision of the Immigration Refugee Board (IRB), The IRB has the power to accept and deny refugee claims within Canada (Moffette \& Aksin, 2018). If coming from a safe country the migrant must also wait at least one year before applying for permanent residency (Moffette \& Aksin, 2018). During the time of waiting for permanent residency the migrant is able to be deported back to their country of origin; meaning, if the Minister deems a country to be safe when in fact it is not, then the migrant is left in harm's way when they are deported. The chances of a country being deemed safe when it is not is plausible because the Minister is in no way obligated to consult a committee or team 
of members of human rights experts to discuss the political climates of other countries thus it is simply a choice made on discretion of the Minister (Moffette \& Aksin, 2018). Not to mention the right to legal action within detention centres and reviews are limited for detainees (Global Detention Project, 2018). There is no estimated amount of reviews that can be conducted that would favour a release which can make the process very mentally strenuous for the detainee to endure. Additionally, the onus relies on the detainee to bring forth new evidence and documents to support their release however many detainees have limited access to resources within detention centres, especially when placed within provincial jails, and their inability to communicate with support systems incapacitates their ability to reach external resources that may help their detention reviews (Global Detention Project, 2018).

\section{Immigration Holding Centres vs Provincial Jails}

As outlined in the introduction, the use of immigration detention centres misconstrues the line between criminal correctional facilities and immigration law. Migrant detainees are held within correctional facilities where they are indistinguishable from inmates. Facility guards and staff are not informed on whom is a detainee or whom is a prisoner meaning they administer the same treatment to every detained person within the facility. Each facility is structured to hold either men, women or families with varying degrees of outdoor recreational areas, daily meals, visitation areas and medical services just to name a few (Canadian Press, 2019). It has been reported that one third of the detainee population are held in prisons (Global Detention Project, 2018). There is only one holding centre in Ontario which is the Rexdale facility that only holds 195 detainees, the rest are held within provincial jails or other facilities. Below is a breakdown of each level of security grade of detention that a detainee can experience, it is beneficial to note, 
that many detainees are transferred between multiple detention institutions and will experience different security grade detention facilities.

Immigration holding centres are specifically designed to hold immigration detainees only, meaning, the only individuals who are kept within the facility are those who have violated immigration laws. These institutions are deemed to be low-security holding facilities due to the knowledge that the detainee has more mobility rights within the centre, detainees are able to seek legal counsel within the facilities and are able to ask to speak to an NGO or legal counsel when they need (EIDN, 2014). Additionally, guards within the facility know that those within the facility are there for immigration violations whereas in provincial institutions the guards may not know who is there as an inmate or a detainee which makes detainees vulnerable to extensive maltreatment from provincial jail staff (Silverman, 2014). Moreover, these facilities are easier to access for visitation by the detainees' support system, for example the holding centre in Toronto is accessible by public transit which increases an affordable option to make visits whereas those in Vanier or Lindsey correctional facilities would need access to a vehicle to attend visitations.

If placed within an Immigration Holding Centre a detainee is still susceptible to getting transferred to provincial jail to remain for the rest of their detention period or for a partial period of their detention (Global Detention Project, 2018). The detainee does not have any legal rights or procedural rights to know when or if they will be transferred to a new facility. The decision is made by a CBSA officer and then approved by a CBSA manager within the facility of placement (International Human Rights Program, Amnesty International, Justice for children and youth, Canadian Association of Refugee Lawyers, Canadian Civil Liberties Association \& Refugee Law Office of Legal Aid Ontario, 2018). It has also been noted that those with mental health illnesses have an increased chance of moving to a provincial jail due to their perceived 
“disruptive behaviour" (Global Detention Project, 2018, p.7). Detainees that are placed within provincial jail must follow the same rules and regulations that the inmates follow. For example, if a jail were to go on lockdown the detainees must comply and follow procedures of a lockdown (Canadian Press, 2019). This can become psychologically and physically endangering for the detainees that are experiencing a high volume of abuse. Even more, it impacts the detainee's ability to receive support since during lockdowns visitors are not allowed in the facility (Canadian Press, 2019), meaning, if a detainee had a visitation scheduled for that day it was cancelled and/or missed due to the lockdown. This becomes problematic because of the locations of provincial jails it is hard to get transpiration to these rural areas; meaning if a detainee misses a visit it can result in them waiting weeks or months to receive another one.

The only way a detainee can be removed out of the cycle of continual detention is through their removal or their release with conditions upon a detention review. Detention reviews are administered with the Immigration and Refugee Board (IRB) under IRPA. During these reviews the detainee presents to the Minister Council how they should be protected under the convention of the refugee. If the Minister Council deems their claims to be unsuccessful then the detainee can administer a habeas corpus claim which is the process where the detainee demands at the federal levels of appeal to allow for a relief from their incarceration by the state (Silverman \& Molnar, 2016). This procedural right was granted through the Chaudhary vs Canada case where a group of detainees advocated that the detention reviews inherently block their right to contest the procedural construct of immigration detention centres, this court case went to the federal court where the judge ruled in favour for Chaudhary. The Chaudhary detainees are also known to some NGO activists and the public as the sufferers (Silverman \& Molnar, 2016). In a habeas corpus claim, the appellants are required to bring forth all the 
evidence and documents to demonstrate that they are being detained indefinitely and that the process is violating their human rights. The detainee must demonstrate that the IRB was fundamentally conducting in an unjust manner, which is challenging and takes a lot of resources that the detainee may not have, such as finances and legal counsel (Silverman \& Molnar, 2016). Thus, detainees do not have many avenues to pursue legal justice even while being detained within correctional facilities.

It is important to understand that "the racialized and gendered nature of migrant detention reveal interconnections between migration, criminal justice, and entrenched legacies of colonialism" (Bosworth \& Turnbull , 2014, p. 2). The intersectional identity of the majority of individuals who make up detention centre populations are racialized men (Bosworth \& Turnbull , 2014). It has been made apparent that migrants are detained based off the notion that they are risky or deviant while also having distinct gendered and racialized lines within the selection of who fits a deviant migrant. Additionally, because of the impacts of neoliberalism and globalization there is an increase on postcolonial penal power to constrain irregular migration to Canada. This becomes important to note as we dive deeper into the paper because immigration detention centres are not simply holding captive migrants, from entering Canada, they are now acting as filters of migration, meaning detention centres are systemically riding migrants whom the government devalues to belong in Canada (Mountz, Coddington, Catania, \& Loyd, 2013). The sense of identity in Canada is continuously contested due to the colonial history of the nation state with Indigenous groups, and because of the high migration rate of Canada it is difficult to state whom belongs to the Canadian identity (Lacroix, 2004). The idea of identity and belonging effects not only migrants but domestic citizens who are marginalized in society particularly racialized first- and second-generation immigrants. 


\section{BACKGROUND}

\section{The Impacts of Neoliberalism and Globalization on Migration}

In the 1980s the global economy was separated into two spheres, the North and the South, which represented the wealth distribution of the globe, this is known as the Brandt line. Countries within the global North are those who hold power and wealth (North America, Europe, Australia and developed countries within Asia) whereas the global South is made up of historically poor countries (Africa, Latin America and Asian developing countries including the Middle East) (Moreno \& Price, 2017). These two spheres inherently depend on each other to stay divided in wealth. The Dependency Theory describes that the wealth of the global North is dependent on the poverty of the global South due to the way their markets interact (Evans, 2018). The global North purchases minerals and natural resources from the global South at cheap rates, which are then industrialized through cheap labour provided by the global South. These products are sold at competitive prices by the global North where the northern countries are able to capitalize off the labour and resources of the South. The global North keeps the profits of the products leaving the global South with minimal revenue and profit to sustain their economy (Amin-Khan, 2015; Evans, 2018). The competitive design of the markets transpires through capitalistic ideologies which encourage for the privatization of the markets which allow for private institutions to accumulate the most amount of money in the most efficient manner (AminKhan, 2015). The efficiency usually occurs through devaluing skills of those in the South or domestic racialized communities in the North.

Neoliberalism is an ideology that encourages a global free market, meaning, private companies and organizations can sell their products at competitive prices. Free markets increase job scarcity in the global South while simultaneously increasing socioeconomic disparities (Moreno \& Price, 2017). In combination with globalization there is an increase of employment 
needs as the economy moves from rural to industrialized. Additionally, globalisation increases the instability of the agricultural sector in the global South, since there is mass employment loss in the agricultural sector, individuals are pushed to move into the urban sectors (Moreno \& Price, 2017). This flow of migration creates an overflow of employment demand within the global South, thus allowing for companies to higher at low wages to increase their product supply (Amin-Khan, 2015). Globalisation is the sharing of knowledge and technology across borders, thus the foundation of globalization lays within producing products to be sold internationally in a competitive manner by institutions (Amin-Khan, 2015). Which supports capitalistic ideals of accumulating the most amount of money in the most efficient manner.

Although there was an increase of the transferring of knowledge across borders the global North does not accept or encourage the movement of people across borders (i.e. migration) (Amin-Khan, 2015). Refugee migration has typically been seen as a south to south phenomenon, meaning, when migrants flee their home country their destination of refuge are within neighbouring countries within the South (Amin-Khan, 2015). This occurs because many irregular migrants want to return home when they are no longer in danger of being persecuted (Amin-Khan, 2015). Economies in the global South have been increasingly facing instable markets due to the impacts of neoliberalism and globalisation, in addition adding the increase flow of refugees there are less and less countries able to support refugee intake. Thus, refugees have started to seek refuge within the global North to increase their social and economic opportunities. Canada has used Immigration detention centres to create boundaries for mobility and immobility within the nation (Bosworth \& Turnbull , 2014).

Criminologist would support the argument that detention centres are used as a mean of deterrence to minimize refugee's ability to migrate to the global North. Deterrence theory 
demonstrates that individuals will assess the harms and benefits of an actions before committing an unlawful act (Patemoster, 2018). Thus, a rational individual would not immigrate to Canada knowing that there was a high chance of them getting detained upon arrival. Immigration detention centres are deterrence mechanisms, meaning it is a physical way for Canada to send a message to refugees to not migrate to the nation or they will be detained. Nonetheless, academics have found that making rational decisions when processing information is not as simplistic. If the individual does not know the impacts of the negative outcomes, they will still commit the act, such as an individual who does not know how long their detention period would be if they were caught. Laws must be clear, publicly attainable and certain for it to be effectively used as a deterrence strategy (Paternoster, 2018).

\section{Constructing 'Refugeeness'}

In the era of mass global movement, the term refugee has been reconfigured to support the influx of people fleeing conflict, violence and dire regions of the globe. Lacroix (2004) uses the term refugeeness to describe what it means to be a refugee from the perception of the refugee claimants themselves. In this paper there will be a use of the term refugeeness to also incorporate the way society and institutional bodies perceive refugees. When government institutions use the label 'refugee' they are referring to 1951 Convention of the Refugees which outlines that a refugee is a person (s) who has a:

Well-founded fear of persecution for reasons of race, religion, nationality, membership of a particular social group or political opinion, is outside the country of his nationality and is unable or, owing to such fear, is unwilling to avail himself of the protection of that country; or who, not having a nationality and being outside the country of his former 
habitual residence as a result of such events, is unable or, owing to such fear, is unwilling to return to it. (UNHCR, p. 6, sec a(2))

Convention refugees are specifically being targeted by political actors which makes the individual unable to seek protection from their government (Khoday, 2016). Additionally, these refugees are granted protection by international law from the signatories of the convention (Khoday, 2016). Nevertheless, there has been a conceptualization of the term 'refugee' because there are now groups of people fleeing from mass violence such as Central American migrants and those fleeing from environment disasters brought on by climate change, also known as, climate change refugees (Albrecht \& Plewa, 2015). According to Cole (2017), the term refugee has two contextual layers, the first would be the legal definition. In the context of Canada this would be the Convention on the Rights of the Refugee definition of the refugee, since Canada is a signatory of the convention. The second layer would be the interpretation of the term refugee since refugees have been portrayed on the mainstream media it effects the way they are perceived (Cole, 2017). The connotations that are attached the term refugee shapes the way a country is able to provide intake resources.

Zetter (2007) views the labelling of a refugee as a politicizing process where the refugee label is granted by the receiving country. A migrant is not recognized as refugee just because they have left their home country; it is only when a governmental body responds and grants the label 'refugee' to the migrant that they are recognized as a refugee. Meaning, until governments declare a migrant or groups of migrants as refugees, they are simply seen as migrants to the state. It is at the point of government recognition where refugeeness transpires for the migrant according to Zetter (2007); refugeeness is a term used by Lacroix (2004) to describe the process 
of becoming and being a refugee. Whereas, Lacroix (2004) interviewed refugee claimants and found that they perceived their refugeeness the moment they fled from their country of origin. The moment the refugee claimant felt they were pushed out of their home country is when their refugeeness commenced (Lacroix, 2004). The refugee claimants compartmentalized their identity in two fragments one being a refugee and the other as who they perceived themselves to be as an individual separate from their immigration status. Lacroix (2004) found that when they spoke about their migration experience, they spoke in terms of being a refugee whereas when they talked about the perception of their own identity, they spoke in terms of their professions from their home country. Additionally, many participants felt that going through the refugee experience was equivalent to a new birth.

Refugees lose not only their homes, they also lose any means of financial stability, friends, family, support systems, a sense of belonging , language and customs. The participants' new birth was expressed in relation to rebuilding their lives in the receiving country and rebuilding their self-esteem. Although these scholars differ on the starting point of refugeeness, both scholars are in agreement that the reading of the refugee alters the acceptance and rejection of refugee claimants (Cole, 2017). For example, in 2015 the Trudeau government created a positive discourse around refugees that focused around the duty of humanitarian assistance of governments (Wallace, 2018). Whereas, the previous Harper government did not encourage refugee acceptance in society and placed refugees in the centre of national security discourse which discouraged societal acceptance of refugees in Canada (Wallace, 2018). Thus, scholars have continuously discussed that being a refugee is more than meeting the criteria of the UN Convention; there also needs to be international and national recognition of the migrant's precarious situation, both in fact and in law. 
Under the Canadian model, the Immigration and Refugee Board (IRB) determines whether a claimant deserves status. The IRB utilizes a quasi-judicial system that determines if refugee claims are factually sound and meet the threshold for recognition, as well as that a claimant is not inadmissible, such as for reasons of security or criminality (Lacroix, 2004). The Board member listens to the stories of the refugee claimants and reviews the submissions, ultimately deciding whether or not they believe the claimant (Macklin, 1998). This means that even if a migrant has legitimate, de facto claims, they may not be granted refugee status if a Board member does not believe him or her.

\section{The Process of the Criminalization of Migrants}

It is important to recognize that during the process of constructing refugeeness simultaneously governments are criminalizing migrants more broadly. Politicians are creating clear remarks that are constructing the racialized other that must be feared (Huot, Bobadilla, Bailliard \&Laliberte Rudman, 2016). Institutions perpetuate this ideology of the other through racist historical belief of maintaining purity in whiteness. The creation of the racialized other starts with treating domestic racialized citizens as second tier citizens within society comparatively to their White counterparts (Huot et al., 2016). In Canada there is a multiculturalism policy that is enacted to create successful integration for different cultures and races whilst decreasing discrimination within the nation (Richeson \& Nussbaum, 2004). Nevertheless, even with the Multiculturalism Act, racism is still prevalent within the Canadian society. There are two main forms of racism:1) macroaggressions, which are blatant acts of racial discrimination such as hate crimes, and 2) microaggression, where this are more subliminal everyday verbal and physical acts that may be intentional or not intentional, such as an individual stating that they are colour blind. The colour-blind ideology is a concept that individuals use to 
state that they do not see colour thus they give everybody the same treatment. Mekawi, Bresin \& Hunter (2017) found that those who claim those statements are simply choosing to ignore the racial discrepancies within society. Additionally, Kolber (2017) stated the colour-blind ideology allows White individuals to ignore whiteness as a factor for their advancement which places blame on racialized individuals for not achieving social mobility at the same rate.

This ties back to Critical Race Theory and the use of meritocracy as a means of ignoring White privileges, since meritocracy transpires through the ideology of working hard to achieve success regardless of intersectional identities (Logan, 2014). These microaggressions transpire into macroaggressions for individuals start to believe that institutions can be built on the ideology of colour-blindness (James, 2011). For example, the Educational system is known to giving a fair chance to every student regardless of race, however, findings demonstrate that racialized students are stream lined into lower paying jobs and into the criminal justice system (Crichlow, 2015). Thus, having domestic citizens already placing racialized individuals at a disadvantage from within. Henceforth, the government attempts to withhold to racialized migrants from entering the nation state.

The language around racialized migrants are the same as racialized domestic citizens within Canada. Racialized bodies are seen as deviant criminals whom commit illegal acts which allows for racialized communities to be policed at a higher rate than White communities (Hari, 2014; Harton \& Broussard, 2015). The disparities between the racialized individuals getting stopped and searched by police comparatively to non-racialized individuals is due to racial profiling. Racial profiling is the concept that details the increased biased held within law enforcement that racialized individuals are more likely to commit crimes which in-turn makes racialized communities to be stopped and searched at a higher rate (Harton \& Broussard, 2015). 
Although racial profiling is commonly used within the discourse of criminal law enforcement, racial profiling also occurs within the realms of immigration enforcement. In July 2019 the CBSA was reported to be sending out immigration officers in Toronto's Weston road and Lawrence Avenue West area which is a heavily racialized population, also known to be a part of little Jamaica neighbourhood. Immigration officers were walking around randomly asking people to show identification to assess if the individual was illegally residing in Canada, a witness stated: "there was a man and woman, both dressed in jeans and had dark jackets, maybe around their 30s, going up to people (all obviously of colour) and taking them aside" (Massa, Jul 2019). The witness comment is reflective of the racial profiling that was happening in these interactions, the witness father even detailed that the officers did not believe he was Portuguese due to his darker complexion (Massa, Jul 2019). This increased securitization around Black and Brown individuals increase their abilities to be detained and taken advantage of by immigration officers and law enforcement.

This local perception of institutional racism gets scaled up into the way the government views racialized migrants; racialized migrants are perceived to be criminals before they are even able to seek refuge because of their race, then the government reinforces this criminality when the migrant crosses an unofficial border point (Hari, 2014). Through this narrow perception of what constitutes a threat allows the government administration to penalize migrants through detention centres. Thus, language and discourse around "legal" and "illegal" bodies is prevalent in allowing for the mistreatment of racialized individuals (Hari, 2014). The terms "illegal" and "criminal" are terms that have a direct negative connotation in relation to the state, which are then placed on migrants to express their relation to the nation. This relation denotes to the Canadian population that allowing migrants into the nation state gives a sense of failed security 
within civilians. Labels are intrinsically designed to enforce state power and control on who has access to state resources and citizenship within the nation (Hari, 2014). Amongst the different classes of migrants that migrate to Canada (economic class, family class, skill labour worker etc.) refugees are penalized the greatest due to their method of travel and due to the ethnic makeup of refugees. Refugees should be seen with compassion and not skepticism, for they are one of the most vulnerable migrant groups. Many irregular migrants have not committed any crimes under the Canadian criminal code they have simply made an immigration violation, meaning they did not come through regulated channels; however, they are being handled in the same manner as criminals that have broken the criminal law (Lacroix, 2004; Goldring et al., 2009).

Migrants should not be penalized for their irregular patterns of migration for many reasons. One prevalent one is that many of these migrants are in situations that threaten their lives and do not have the time nor the access to apply for refuge from their home country. Another reasoning is that the global North is an actor in creating the instability for the violence and conflict within the global South and thus should take an active role in revitalizing the lives of those effected (Albrecht \& Plewa, 2015). And lastly, the laws and regulations around refugee claims push migrants to informal channels of migration. The Third Safe Country agreement between Canada and the United States push migrants to use more dangerous routes in seeking asylum because it impedes their decisions on where to migrate (Lacroix, 2004). The Third Safe Country agreement is an understanding between the three countries that deem a migrant must make their asylum claim within the first country of entry (Lacroix, 2004). Meaning, if a refugee lands in the United States and tries to come to the Canadian border to make a claim they will be denied and sent back to the United States because the US is deemed as a safe country to make 
their asylum claims. Migrants have found a loophole to this agreement, this agreement only refers to official border markings, thus migrants have been taking different routes which lead them to cross over unofficial borders (such as large forestry that are not official border check points) (Lacroix, 2004). Through crossing unofficial borders migrants have regained their right on choosing where they want to resettle and make their refugee claims.

\section{The Impacts of Immigration Detention Centres}

As discussed above immigration detention centres act as spatial deterrence for migrants to migrate to Canada through irregular avenues (Mountz et al., 2013). Spatial deterrence are physical barriers that induces an individual to weight out the options of committing a crime in hopes that the scales of good and bad will weight in the favour of the individual to not commit the act (Mountz et al., 2013). Governments want to be able to select the types of migrants that enter the country. Many countries simply want economic migrants and not aid refugees or other lower-class migrants into their country because they are seen as a burden to the state (Lacroix, 2004). Canada has publicly mentioned that their economy would not be stable without immigrants, Canadians are not populating enough to satisfy the labour market thus Canada intakes migrants to fill that gap (Kaushik \& Drolet, 2018). Thus, immigration detention centres are designed to stop refugees and asylum seekers from immigrating to Canada because they are not perceived to be beneficial to the government. CRT describes this in the first tenant as

allowing racialized individuals advancement, as long as, it benefits primarily the advancement of Whiteness (Logan, 2014). Thus, detention centres are built to ensure the only migrants that are within society are those whom are viewed as worthy of being in Canada, meaning, the migrants 
that are able to advance Canada's economy. Those whom do not satisfy the needs of the Canadian economy are susceptible to detention and mal treatment.

Immigration detention centres are not built in a way that support the physical and mental well-being of detainees. Immigration detention centres have shown to increase the decline of detainee's mental health due to the trauma they experience being inside confinement. Detainees have pre-existing trauma from their migration from their home country to their receiving country. This trauma is magnified once migrants arrive in the receiving country which is supposed to provide them safety, stability and a sense of livelihood, and instead they are detained and exposed to further abuse. Puthoopparambil et al. (2015), found that interaction with guards within the facility impacted the mental health of detainees the most. Detainees mental health decrease when guards called them by numbers instead of by their name and also inflicted physical harm and threats to physically harm detainees (Puthoopparambil et al., 2015). Additionally, guards expressed that detainees with pre-exposed traumas such as depression and post-traumatic stress disorder (PTSD) are perceived as more of threat thus need to be handled with more force compared to detainees who do not suffer with severe mental health illnesses (Silverman, 2014). Detainees that are in correctional facilities while awaiting their detention review and are suffering from mental illnesses are frequently placed in solitary confinement. Solitary confinement is when a detainee or inmate is placed along in a single cell with a small window, a toilet, a sink and a mattress (Shaley, 2017). Solitary confinement has been proven to decrease mental health of those placed within it for multiple days due to the extreme isolation (Silverman, 2014). Placing an individual in solitary confinement for weeks straight is viewed as unusual and cruel punishment. 
In 2018 the Canadian government was sued by a 36-year-old man named Prosper Niyonzima for having a mental breakdown induced from solitary confinement. Niyonzima was an immigration detainee from Burundi who lost his permanent residence status in Canada and placed in detention, his detention lasted for 5 years and 760 days of those 5 years he was placed in solitary confinement (Keung, Nov. 9, 2018). Upon being placed in detention, the facility staff was notified about Niyonzima mental illnesses that stem from his PTSD from the Rwandan genocide where he lost his entire family, however, Niyonzima was denied mental health resources within the facility (Keung, Nov. 9, 2018). Niyonzima states that he was "denied proper food, clothing, medical care and yard time and was permitted to take only three showers over the course of a year. He alleges he was also subjected to 'painful and forcible' electroconvulsive therapy” (Reddekopp, Nov. 10, 2018, I[4). Like many detainees Niyonzima was transferred between many detention facilities within Ontario; Toronto West Detention Centre, the Central East Correctional Centre in Lindsay, Ont., and St. Lawrence Valley Correctional and Treatment Centre in Brockville, Ont. (Reddekopp, Nov. 10, 2018). The lawsuit is being made for $\$ 65$ million compensation for making Niyonzima catatonic for three years from the trauma he experienced within migrant detention (Reddekopp, Nov. 10, 2018; Keung, Nov. 9, 2018).

Niyonzima demonstrates an experience that many detainees face, the coercive treatment by the guards, the detrimental mental health impacts and indefinite detention period that lasted for years. This case can be used to demonstrate the dire need for change within immigration policy surrounding migrant detention. Detainees have expectations when they are migrating to Canada. Being held in detention was not a part of their dreams to gaining access to the opportunities that Canada declares to provide immigrants. The World Health organization states that a person's quality of life is an “'individuals' perceptions of their position in life in the 
context of the culture and value systems in which they live and in relation to their goals, expectations, standards and concerns" (Puthoopparambil et al., 2015, p. 2). Detainees are giving a poor quality of life when they are arriving to Canada and are placed in detention centres. Refugees are fleeing their home country's conflict and violence to gain access to safety, economic advancement and social acceptance within Canada, and when those expectations are met with detention it reinforces past traumas and instills new traumas within the detainee. With the mal kept conditions of the detention centres and the ongoing mental and physical abuse detainees are embarking on avenues to create change within their environments.

\section{Resilience within the Detainee Community and their Support System}

Scholars have used the resilience in regard to migration to explain the overcoming of adversities that migrants face. Resilience is concept that has been studied by many scholars (Hall and Lamont 2013), it originates from the Latin word 'resilar' which means 'leap backwards', the concept is now theorized differently in different disciplines (Plodinec, 2009). For the purpose of the study there will be focus on the social approach to resilience used by scholars in feminist theory and critical race theory (MacKinnon and Derickson, 2013; Luthar, 2006; Magis, 2010; Murray, Mucherah \& Jones, 2000). Resilience is used to describe an individual overcoming adversity and is used to analyze the individual, community and systems to survive those challenges and to transform when required. Migrants are required to be resilient throughout their journey of immigration process due to suffering great loss and grief from loss of customs, family, friends and language, and their settlement process relating to education, accessing employment and affordable housing (Thomas, 2013; Michail, 2013; Lester \& Nguyen, 2015; Lee, 2005). 
Critical theory scholars argue the concept of resiliency is influenced by neoliberalist norms and values because it decreases institutional involvement to create a more inclusive society and places hardship on the individual to overcome systemic barriers. It is important to note when speaking of resilience, it is always in reference to adversity, unforeseen circumstances, stress, uncertainty, change, a threat, shock, hardship and violence. Thus, there needs to be an acknowledgment that there are particular groups that have to be resilient within the way society is structured. Thus, resilience is a socially constructed concept because it innately depends on social barriers and hegemonic systems existence (Cretney 2014). Resiliency continues to place hardship on the marginalized group to overcome systemic barriers to accept social norms of the dominant group, however, there is rarely a discussion on how institutions are resilient and are changing to accommodate those who are not represented or accepted in institutional spaces (i.e. marginalized groups). Academics have discussed reframing the concept to include social justice action within the framework which incorporates the notion of self, community, and society (Cretney 2014; Joseph 2013; MacKinnon \& Derickson 2013). The most common definition used for social resilience is "the capacity of groups of people bound together in an organization, class, racial group, community or nation to sustain and advance their wellbeing in the face of challenges to it" (Hall \& Lamont, 2013, p. 2). Hall \& Lamont definition of social resilience is reflective in the Anti-Oppressive framework which is described as marginalized group dismantling oppressive system through social justice work such as protest, demonstration and campaigns.

Immigration detainees have faced challenges like no other migrant group in Canada since they experience detention on top of racial, gender, religious and other socioeconomic status barriers of marginalization that is faced by other migrant populations (Lacroix, 2004). The mal- 
treatment by the guards and other cellmates have brought with the combination of punitive immigration policies have made detainees in Ontario enter into a hunger strike as of September 2013 and again in October $17^{\text {th }} 2016$. It started with 17 detainees striking to prohibit their transfer to Lindsey maximum security prison and to address indefinite sentencing in Canada. Hunger strikes are a form of peaceful political protest through the removal and refusal of food (Conlon, 2013). This form of protesting has been shown to be persuasive because it hits to the core of humanity. Looking at Maslow's Hierarchy of Needs the first basis of needs that humans innately need to survive is food, water, warmth and rest thus if detainees are intentionally removing and refusing food knowing that it will create a direct effect to their ability to survive is powerful in itself. Annas (1995) describes it as, “hunger strike comes from the striker's sworn intent to die a slow death in public view unless those in power address the injustice or conditions being protested" (p.1114) Food is a source of energy that is to be intake and dispensed, this is known as ancestral food environment, it is the originating and common knowledge of food (Conlon, 2013). Hunger strikes have been known to trigger emotions in other people because it brings empathy and guilt to those watching the movement because food is a vital need of all living things (Annas, 1995; McLeod 2007). Furthermore, food is used to bring communities together, to heal and learn about one another. Canada being a multicultural society has used food to integrate the diversity of the country and also has used food as a learning tool for integration.

Other political actors have shown that hunger strikes are a viable option for creating change within an oppressive system. Prison inmates, those incarcerated for violating the criminal code of Canada, have gone on strikes to protest the living conditions of correctional facilities (Sheppard, 2018). Inmates face many of the same oppressive systems that detainees face such as physical abuse and threats by guards and severe mental health impacts. Hunger strikes have 
gained inmates employment and educational opportunities while being imprisoned, however, there is still more initiatives being done to increase the quality of those services. While detainees are engaging in hunger strikes activist and immigration lawyers have been speaking with media outlets and social media to help change the narrative around immigration detainees. There have been protests and demonstration that explain the psychological damage of indefinite sentencing. Immigration lawyers have spoken about their clients engaging in hunger strikes and how they are concerned for their health and safety yet understand the reasoning for their hardship. Changing the narrative around detainees and detention is very important because it rids the collective mind of myths about detainees (Pastor \& Mollenkopf, 2012).

Social resiliency in Canada has made space for positive changes for the detainee community. In response of the hunger strike and push from NGOs, mainly from detainee and migrant based non-governmental organizations, administration officials have reassessed the detention process. The Canadian Border Agency (CBSA) has made efforts to reach the demands of immigration detainees to put an end to indefinite detention where applicable through creating alternatives to detention. If a detainee, of permanent residence status or a foreign national, can demonstrate that an individual of status in Canada can act as a bondsperson they are eligible to be release with conditions (Bosworth, 2018). The third-party bondsperson "act as a guardian and assist clients to ensure their compliance with any and all terms and conditions and provide them with social support that will enable them to comply with immigration requirements" (CBSA quoted in Bosworth, 2018). Moreover, CBSA introduced electronic supervision which enables detainees released on conditions to be tracked electronically and enables voices registration and recognition for reporting purposes (Bosworth, 2018). For detainees who do not have family/kin or bondsperson they can join the Toronto Jail Program where the Bail project acts as their surety 
(Bosworth, 2018). Although CBSA has provided alternatives to detention there is still minimal information on the positive effects that the alternatives have on detainees. Moreover, there is minimal information on the access or successful rate of detainees being placed in alternative programming. Thus, there is still a need for community pushbacks and campaigns to dismantle the systemic oppression that detainees are facing.

There are ongoing forms of resistance that are continuing within the community; these campaigns cover different forms of detention such as irregular migrants, labour migrant, permanent residences and children migrants. End Immigration Detention Network is a coalition of organizations that work with detainees and their families to end immigration detention (EIDN, n.d). EIDN is formed of No One is Illegal- Toronto, Fuerza Puwersa, End Immigration Detention Network Peterborough and Vancouver and No One is Illegal- Ottawa, each of these organizations are migrant focused groups which fight for the rights of non-status, undocumented, labour migrants and irregular migrants. Additionally, the Canadian Council of Refugees run an end immigration detention of children campaign which specifically focus on the detention and continued detention of children (CCR, n.d). The mere existence of these organization forms the basis for community mobility to shape society. NGOs make space for detainees to dismantle detention institutions and allow detainees to speak their truths to society in hopes for institutional change.

\section{THORETICAL FRAMEWORK: CRITICAL RACE THEORY}

Critical Race Theory (CRT) examines race as a socially constructed concept that is used to oppressed racialized individuals through institutional systems. Racialized individuals go through a process of racialization which, is the process of interpreting the individual's character based on the colour of their skin. The concept of racism is where marginalized individuals face 
institutionalized prejudices and discrimination due to their race. Crichlow (2015) argues that marginalized races are associated with negative connotations to devalue the person in comparison to the dominant culture (i.e. White individuals). There are systemic factors that places racialized individuals at a disadvantage in society in comparison to whiteness. An example is social mobility, White individuals are able to enact social mobility based on racial appearance and it has been shown to benefit White individuals and not racialized groups. Furthermore, within the criminal justice system there is a clear discrepancy between the mass incarceration of Black individuals in comparison to White individuals. Since statistics show that there is a 6:1 ratio of Black individuals that are incarcerated compared to White individuals it can be said that racism is at play in the criminal justice system (Blumstein, 2015). As spoken about above there is clear demonstration that racism exist within detention centres because the majority of individuals within detention centres are racialized men. Given the linkages between criminal punishment and migrant detention, CRT can reinforce and advance standard crimmigration perspectives by highlighting the distinctive dimensions of race and racism. Which is why there will be a use of CRT to demonstrate the institutionalized racism that exist in immigration detention centres.

Crichlow (2015) breaks Critical Race Theory into three tenants; the first one is that institutions only allow for racialized advancement when it becomes beneficial to white power structures- this is known as interest convergence. In the field of immigration, CRT would argue that the Canadian government allows racialized migrants to immigrate to Canada with the sole purpose to stabilize the economy. Canada grants the ability to allow racialized migrants to migrate and resettle in the nation only when it is encouraged for economic purposes of the nation state not for benefits of the migrant (Crichlow, 2015). Second, White individuals have the ability 
to not acknowledge racial disadvantages due to the colour-blind ideology, which is the belief that everyone is treated equally within systems regardless of race (Crichlow, 2015; Doane, 2017). Immigration detention centres is a system that simply detains migrants on the 4 grounds of detention outlined by the government it does not explicitly state that racialized migrants will be targets to be detained. Nonetheless, immigration detention centres are detaining racialized men at an exceedingly higher rate than White men, which is caused by institutional barriers produced through neoliberalism and globalization. Lastly, due to the disregard of race as a mobility barrier CRT believes that White individuals use the meritocracy argument to further sustain white supremacy (Logan, 2014; Crichlow, 2015; Kolber, 2017). The Canadian government has categorized migrants to establish which migrants are accepted and wanted within society and which migrants are not. Simply stating that irregular migrants are illegal migrants and those who migrate through other avenues (i.e. family class and economic class) are seen as legal migrants, this places inclusionary and exclusionary labels on the migrant (Zetter, 2007). Economic migrants are seen as deserving of their place in society because of their financial status when migrating, these migrants bring value and stability to the Canadian economy. Whereas, refugees and other irregular migrants are seen as burdens to the state and are underserving of seeking refuge within Canada because they do not come with the same economic status as economic migrants (Lacroix, 2004; Zetter, 2007; Crichlow, 2015). Through these three tenants' readers can illustrate the racist language that is ingulfing irregular migrants which enforces an ideology that allows for government institutions to maltreat irregular migrants, such as detainees.

Moreover, CRT is useful for studying migrant detention because it emphasizes the use of narrative building and storytelling to express the lived experiences of racialized communities to induce understanding and healing for communities (Delgado, 2017). With the use of CRT, I will 
be sharing the narratives of NGO representatives in their own words to express their experiences interacting with detention centres. This ties into showcasing the detrimental effects that racist institutions have placed on racialized communities and how policies and institutional structures need to address this historical bias that is carried within Western countries such as Canada. Additionally, this research will speak to institutional actors such as NGOs representatives to shed light on what needs to be changed within institutions to restore justice to detainees. CRT believes using activism to change narrative of a marginalized community is powerful in itself. The power of changing narratives through a CRT lens has been demonstrated in the United States with Central American migrants engaging in protests and demonstrations to challenge mainstream medias picturing on detained migrants in the United States and Central Americans (Luchies, 2015; Figueroa, 2017). Students have taken over college campuses to tell their stories and place themselves in the light to demonstrate that those who are being detained by immigration officials are not criminals, or illegal beings. Instead these activists are showcasing the everyday undocumented migrant, those who were brought when they were younger, or those who are suffering and need refuge (Figueroa, 2017). Through these demonstrations mainstream society is able to be compassionate and empathize with undocumented migrants which in turn removes the complacent allowance of mass detention of undocumented migrants in the United States. Thus, Canadian NGO actors are establishing the same method of activism to relieve detainees from the false imagery that politicians have constructed as detainees.

\section{RESEARCH ANALYSIS}

Immigration detention centres are a growing phenomenon in the Western society and not many researchers are delving into the topic on how detention centres are affecting racialized detainees and how NGOs gain access to supporting detainees within detention centres. There are 
many other groups that also are affected by immigration detention centres that are not analyzed within this study such as detainee's family and friends, detention facility staff and officials, and more. The major findings from the interviews that were conducted can be categorized into four major themes; Race at Play which discusses the possible racially motivated procedures and implementation of detention centres, Health and Wellness of Detainees which focuses on the impacts of detention centres on detainees mental and physical wellbeing; Support Challenges, this theme demonstrates the hardship that advocates, professionals and detainees experience within immigration detention centres, the policies and regulations around detention, And Activism within the Community which details the movements that have been used to support and advocate for detainees within detention centres.

Each major theme will be explored and analyzed through sub-categories to fully understand the experience and meaning of the experiences of the participants. All findings will be explored through a phenomenological approach which pulls direct quotes from the participant to create a full narrative of their experience. Thus, through the quotes of the participants there is hope to construct an understanding on how immigration detention centres impact the lived experiences of detainees through the lenses of NGOs whilst demonstrating the constant challenges and barriers these professional groups face while interacting with migrant detention policy and practices. The themes below were constructed through the transcription and coding of the interviews with the participants.

\section{Race at Play}

The first theme is Race at Play, many of the participants discussed their inclinations to believe that immigration detention centres are racially-influenced institutions. Participants in the study explained how most of the detainees in detention centres are Black and Brown individuals 
and they also identified that indefinite detentions affect Black populations more than others. In the two sub-heading below there is a more detailed view on how racism transpires through immigration detention centres and how it is affecting detainees and the Black and Brown communities at large.

The Mass Detention of Black and Brown Individuals NGO activists do not believe that it is a coincidence that immigration detention centres are heavily populated with Black and Brown individuals. NGO perceive detention centres to be a space for the government to systematically oppress racialized individuals. One participant expressed their disbelief through the following statement:

"I don't believe that like oh it's only this very... seems to me uhh racialized uhh coming from one region of Africa, West Africa who makes a majority of it saying uhh that they're the only one fucking up their status I don't believe that, I know obviously I actually know that there is lots a non-status people who work and live in Canada who work probably under the table I'm sure commits crimes all the time umm and their not putting in like they're not put in maximum security prisons right so like umm I mean I actually hold the position that like immigration detention is an extension of Canada's Anti-Black racism" - Participant, 1

While another participant exclaimed their frustration about immigration detention centres being an inherently racist institution:

"the fact that immigration detention centres are holding and detaining mass amounts of Black and Brown folks is outrageous to me, that the government has the audacity to continuously systematically rid Black and Brown folks of their freedoms uhhh and rights as a human being. Like as humans we have innate rights but time and time again it shows that only a certain group, white people, are the only ones that are able to have those rights respected." - Participant 3

It was not only that immigration detention centres were grossly detaining racialized individuals, it was also perceived by the participants that the government was constructing a hierarchy of cultures and races through which was demonstrated through the arbitrary placement of detainees. 
"I think it's all subjective like who decides, who gets to decide which prisoner goes, you know, personally I think it's around race, but I can't claim that because I think we need to have a study on it but from my observation it is, uhh I see a lot more West African people in Central East Correctional facility umm and like a lot of like more Arab and Mexicans in like Rexdale and also in Toronto east right so like what is this kind of like hierarchy of like for immigration detainees there's even way differences in the way that they're treated obviously we know that like uh the longest detainee who was South African was ten years, he was there for ten years, just because they couldn't identify him right, Ahmed was there for 5 Hussein was there for 3 , again these are people that are there that actually don't have crimes." - Participant 1

The participants drew out that the placement of detainees seemed to be purposeful, meaning those of a lighter complexion were placed within less securitized facilities such as Rexdale whereas darker detainees were placed within maximum and medium security facilities. The participant also drew out details that noted that the individuals who are being held in detention centres for years, instead of days and months, were Black men. There is a clear racial and gendered lining that is occurring within detention centers, the over representation of racialized men in detention centers alludes to the results of institutional racism. CRT views overrepresentation of racialized individuals to their White counterparts within oppressive systems as direct data to demonstrate systemic racism.

Addressing the Needs of the Black and Brown Community

Many of the participants spoke about the imbalance between the advocates and the detainees in regard to race, many of the advocates that the NGOs were composed of are White individuals. This became an issue because there were particular needs that the Black and Brown community needed to address that were not being viewed or expressed through NGO groups.

"most of the people that like we were supporting were Black and in the beginning virtually [there were] not Black people like in the organizing ... so like highly problematic *laughs* kind of started this thing and hadn't addressed the concerns that like other like Black people in community were like bringing up umm so like that was like a thing umm and but then it's like, what do you do like just like the dynamic of like 
bringing people in cause then you're like now we have to bring Black people and that's like extremely tokenizing" - Participant 2

These issues became prevalent when detainees expressed feelings of historical injustices of the Black community:

"like most of the people in detention are like Black or Brown right like and a lot of detainees who would call would be like I feel like a slave, this is what I feel like, on lock down, we're always in our cells or cuffed"- Participant 2

This generational trauma is prevalent in the Black community due to the mass incarceration of Black men in the criminal justice system, it is during these instances where the voices and support of Black activists are needed. Additionally, there are intersectional identities within the racialized community that were being seen and not fully addressed because of the perception of racialized men. The gendered and racial aspect impede the rights of the detainees to be granted emotional and mental support throughout their detention process:

"yeah it really degraded on people like and now like there's a lot of people who are released and like most of the guys that I talked to have like ongoing mental health issues that some people are addressing them but like it's also men and racialized men so a lot of people are not and like it really effects people like their free technically but like but that stays with you, you know."- Participant 2

Immigration detention centres are reflecting the same injustices towards the Black community that the criminal justice system is inflicting. The trauma of mass detention of Black individuals is seeping into the community and triggering generational pains of slavery. Whilst, not providing support to those suffering which increases the perception of racialized men having to be strong and withhold their emotions. 


\section{Health and Wellness of Detainees}

The second theme is Health and Wellness of Detainees, during the interviews conducted the participants went into great detail about the health and wellness of the detainees within the detention centres. This became a prominent discussion for each participant as they described how their client's health and wellness decreases within each interaction that took place between the professionals and their clients. It has been studied that immigration detention centres have a direct impact on the wellbeing and quality of life of detainees (Global Detention Project, 2018; Tam, 2017; Kellezi \& Bosworth, 2016; Puthoopparambil, et al., 2015; Silverman, 2014). According to the Global Detention Project report, "detention causes psychological illness, trauma, depression, anxiety, aggression, and other physical, emotional and psychological consequences" (p. 6). These conditions can have lasting effects on detainees which mal equip them for release into society when giving the chance to establish themselves in Canada. During the interviews with NGOs that support detainees they speak about the declining conditions of detainees physical and mental health while being detained, as they have witnessed it and how they have been told. Throughout the interview's participants described how they were viewing the declining state of their client's health one participant explained:

"you can really tell that his health was deteriorating, his mental health was deteriorating and uhh he wasn't getting proper care obviously"- Participant 1

While another stated:

"just listening to the ways former detainee speak about the urgency in which things need to be changed within immigration detention centres, they express that detainees are feeling isolated within the centres and that the lack of access to their supports, like family and friends is creating a burden on them. And not to mention the mental health impacts that has on them to be navigating such a complex system on their own and finding the finances to support themselves through the costly process of making claims and getting lawyers. There's so much at stake for them and the system is just exploiting them completely"- Participant 3 
After commenting on the overall health and wellbeing of their clients declining mental and physical state and alluding to the lack of care that they were receiving; the participants gave details about some of the encounters that they have heard and seen for themselves. Below are two sub-themes, unwarranted punishment, which details about the punitive practices of immigration detention centres and the deterioration of mental and physical health, which speaks to the mental and physical changes of the detainees that were noted by the NGOs.

\section{Unwarranted punishment}

Participants described the unwarranted punishment that was directed towards immigration detainees. There was acknowledgement that indefinite sentencing was the key punishment that all immigration detainees were facing as one participant describes:

"the fact indefinite detention justifies the maximum-security prison,... I think because we don't have capital punishment so the ultimate punishment right now is indefinite detention and definitely you put them in the same category as like criminals, like serial killers, like people who deserve maximum security."- Participant 1

While another participant alluded to continual punitive behavioural practices of immigration officials throughout the detention process

"then they[Minister Council Representative] were basically just like punishing him because like they were like 'well here we're going to take something that is your right because you're pretending that you need access' you know and sometimes I think about like oh my god, like what more is happening if I see one"- Participant 1

In this instance the participant is speaking about how one of their clients lost their hearing and was requesting support from the IRB for their detention reviews and instead of being provided 
accommodations the detainee was accused faking the need for accessible treatment and was the

removed from their detention review, as the participant continue to explain:

"I would attend his detention reviews and they would be like you're not really deaf so we're not going to... like close captioning and also... like it was just be like so like you can really tell that in the detention reviews they really assumed that he was just really pretending so like they'll talk to him and be like 'well ok like if you can't hear us anyways you don't need to be here so we'll just continue on with the detention review and then you can just go"'- Participant 1

\section{Deterioration of Mental and Physical Health}

The punitive environment of detention centres manifested into the deterioration of detainees

mental and physical health during their sentence period. One participant who remained in contact

with detainees over a phone line noted the changes in detainees' demeanors and voices:

"Like on the phone I would notice people's like demeanor changing so like people talking like in like manic umm or developing like stutters when they didn't have stutters or like getting really quiet umm and obviously, you're heightened to certain things cause you're not seeing people so what you are noticing is their voices right"- Participant 2

Another participant describes how one of the detainees that they were supporting suffered from multiple health complications when they noted that:

"people who were in jail for uhh very petty crimes or like, or crimes that they have already served for or actually they didn't commit anything because they just don't have proper documents or the country of what they say is "origin" will not take them and so umm so for example like umm visiting Hussein who resisted his deportation and got heavily injured from that right"- Participant 1

"Hussein was like lost his hearing, was like paralyzed in like half of his body"Participant 1

These are just a couple incidences of the impacts of immigration detention centres have on the wellbeing of immigration detainees. Indefinite sentencing allows detainees to experience these traumatic events repeatedly for years. 


\section{Support Challenges}

The third theme identified was support challenges, naturally being an activist for marginalized groups come with many challenges and barriers. Each participant explained the difficulties of advocating for detainees in times where there was not a lot of attention placed on helping or understanding the detainee community.

\section{Procedural Barriers}

The rules and regulations are different for each immigration detention centre depending on the security grade of the facility at hand. These differences effect the ways NGOs can support immigration detainees within the centres, one participant explained the complex nature of even being able to visit one of the detainees:

"Toronto East Correctional facility introduced like a visitation list so you can only have like 6 people in your list you need to have all their information and you have to submit their ID, so you have to have ID, and uhh and then the list can only be renewed every 30 days you so like you can't be like I'm free on Wednesday but if you're not on the list, cause before anyone can show up and visit you, so you don't have to let them know, you know, I mean we have to call ahead of time but we don't really have to like, it's not 30 days before, because now you basically have to have a 30 day notice to visit, right, and it's not even that easy, because you have to get, it's the person inside that has to submit the name so like you have to like try to call them, or mail them, to be able to have to submit all this information about yourself, and then they still have to submit it and get it approved so it's not really 30 days and so like that definitely made it very challenging to do the visits"- Participant 1

Additionally, two participants continued to detail their observations at the detention reviews

where they expressed concerns around the IRB members that are chosen to determine claims:

"I'm constantly just think about who these officials are and who these officers are on the other end who are approving and disapproving these claims, do they have a race based analysis? Do they have an understanding of oppression? Do they know like how much, like how much do they about these people country of origin? Are they a compassion based person? Are they an empathetic person? How much are they getting paid? Are they unionized? Like there are so many things that I'm like how do people on the other end like justify their role"- Participant 2 
While the next commented on the IRB members qualifications be in the position to make these choices:

"attending the detention reviews was really uhh eye opening the fact that umm any person who knows like very basic uhh due process, any court proceedings whatever would actually I think could identify that the proceedings are very confusing, uhh it's seems like there was no really rule of order. The fact that the judges can be, they're not lawyers, they're not people who actually studied law, and you can really see that'Participant 1

The concerns around the IRB member stems to the point of not knowing how to advise the detainee on what to do during their detention review because it varies depending on who is hearing your case. Thus, it leaves advocates being at a loss when being able to provide guidance throughout the process because there is no structural integrity to detention reviews. Coligado (2018) study echoes these findings when legal professionals question the quality of the IRB members discretion and even point to the possibility of their decision being influenced due to the highly racialized makeup of the detainee population. The ability for administrative officials to continually place a detainee in detention based on their discretion becomes problematic when that discretion lies within a system that gives space for arbitrary punishment.

\section{Activism within the Community}

The last theme identified is Activism within the Community each participant spoke about their involvement to advocate for detainees in their own capacities and how that transpires. The two main overlapping movements were the hunger strikes that was demonstrated by the detainees within detention centres and a phone line that kept the detainees and NGOs in contact to develop support plans and actions in a holistic way (i.e. activism within detention centres and outside detention centres). Furthermore, many of the activist had lists of changes that they 
wanted to see implemented by government officials to ensure the safety, care, and release of detainees within immigration detention centres.

\section{Hunger Strike}

"in 2013 No One Is Illegal umm got a hold of someone who is a part of our group and said that there was this historic hunger strike that is happening umm and that like we, if we wanted too we should basically be a part of it... so it was us no one is illegal and then like a EIDN chapter in Peterborough because the hunger strike was happening in Lindsey umm which is like a town like maybe half an hour away from Peterborough so they didn't really have a group and because they were in such close like proximity they like started a chapter"- Participant 2

This hunger strike was the one of the main triggers in building a support network for immigration detainees. Detainees used this hunger strike to advocate on the changes that they want to see within immigration detention centres and grabbed the attention of government official and the public.

Phone line

When the hunger strike began a detainee support group started a phone line to stay in contact with the detainees held in jails. This phone line became one of the only support

mechanisms that the detainees could access which placed a huge burden on the phone operators:

"when we started obviously there was like almost 200 people on hunger strike so like the phone line was like popping like it was crazy like because there was no hours and it was just the two of us like it was like I mean I was fortunate enough to have a job that I can just pick up phone calls but the phone would be ringing like off the hook, like all the time"- Participant 2

\section{Changing the Narrative}

When discussing with participants there was a clear depiction of the detainees that the interviewees wanted to get across, which was that detainees are just everyday people that have been unfairly marginalized and penalized by the government. There is this perceived criminal depiction of detainees that is illustrated to society through the media and the government actions of detention, which is erasing the truths of who the detainees: 
"every time I try to talk to people who are not informed about Canadian detention centres, they have a strong gut reaction to just be thankful we're not in the US. And it gets really frustrating because you will be talking about people's human rights being violated here at home in their own country and the person is just not listening or understanding. And so the US media consumption helps Canada hide behind this lie that we are a refugee accepting country when in reality we're bringing them in and then detaining them indefinitely"- Participant 3

Another participant detailed:

"I mean like I'm saying just crudely, cause the audience are people who don't know these people, but like you know they're like people like us you know; people who have interests and have histories in Toronto, like grew up in Toronto. We would meet people in immigration detention centre who grew up in Toronto since they were like 5 you know but like they just got like a juvy offence and they never got their citizenship"- Participant 2

Lastly the participants found that the way their viewed is based on their precarious status which devalues your contribution and participation in society:

"like I said spoke to three people today who have warrant out for their arrests right, every day people, and that's who's in detention like every day, every day racialized people and so like I would like to see everything scrapped like I don't like I think that like we need to find ways to like regularize people statuses"- Participant 2

CRT supports the notions of changing the narrative around racialized communities because it is the language and depiction of racialized people that allows for their maltreatment from institutions. When society is actively devaluing a group of people it leaves space for those in power to take advantage of societies lack of care to mistreat said group. Racialized detainees threaten Whiteness within the Canadian state and the government has used language and negative narratives of "illegal" and "criminal" migrants to justify the use of detention centers. Thus NGOs are using their power to pushback on that narrative to demonstrate that detainees are “everyday people". 
Recommended Changes to be Made to Uplift the Detainee Community

Each participant gave direct lists of what they would want to see changed within

immigration detention centres and there was four points that were repeated amongst all the

participants.

(1) To implement a 90-day release cap on immigration detention centres.

"the overhauling the adjudication process which is like detention reviews and then end to indefinite detention and implementing a 90 day detention period"- Participant 2

"like federally, like no political party has like a platform to only propose a 90 day limit. I think it's precisely because it would create such a huge huge tension in the Canadian society because now they're touching that I think what they put in a pedestal this sacred mechanism of immigration detention umm and I think like Canada completely uhh as like a you know it very contradictory because their seen as a benevolent country the fact that they're actually violating human rights law because of the indefinite detention um so yeah. So 90 day limit that would be great"- Participant 1

(2) Remove maximum and medium security prisons out of the options for detaining immigration detainees.

"I want to see right, the removal of immigration detainees from medium and maximum security prisons and just move to low security immigration detention centres"- Participant 1

"I think maximum security prison should be out of the question for immigration detainees uhh I mean it's again like this would be a hard thing like they will be like 'sure! we'll make more immigration detention centres' you know like, I know they have already expanded the Rexdale immigration detention holding centre"- Participant 1

(3) Increase the accessibility to detainees being held in immigration detention centres

"are they moving people from Vanier all that, that's what I want to see right, the removal of immigration detainees from medium and maximum security prisons and just move to low security immigration detention centres where they can access visits, they can see their families, umm It's easier to see them you know uhh if they're in locations that are accessible by transit than like their and that their uhh their detention reviews will be viewable to the public easily."- Participant 1 
"how can you even prepare detainees for that it's really hard to contact them. Umm Letters take a while and letters get read too, so they open it and read it before, sorry the guards read it before you know. The fact that there's so much censorship they're really treat in maximum security, it's not like there's a pod that's medium and then the rest are maximum, like everyone maximum you know."- Participant 2

It has been shown that lengthy detention periods that migrants are facing is due to the lack of NGOs services and legal services that cannot be reached from rural areas (Gauvreau \& Williams, 2002).

(4) Protect permanent residence statuses and regularize everyone's status

"I don't think people should be able to lose their status when their permanent status, when you're permanent, you're fucking permanent"- Participant 2

"for Toronto where are immigrant population is very high, permanent residences are stripped of their status when they are convicted of a crime of 6 months or more, like the fuck is that, like the smallest petty things could get someone stripped of their status just like that... ummm so yeah that should not be allowed or be a thing that happens, they have worked for their status here and that status should be their promise to citizenship"Participant 3

The participant even went as far as giving an example of a model that Canada could

follow to start giving people status within the country to decrease the use of immigration

detention centres and a model that protects the rights of permanent residences.

"Spain passed policies where they regularize large amounts of peoples statuses and I think that like a good first start with Canada, I mean they're never going to do it, but like a good first start would be to regularize everybody's status who doesn't have status"Participant 2

Through regularizing individuals' status, it prevents society from claiming that illegal migrants are taking advantage of the nation state. Since every person will be identified and have a place within society to access resources and have social mobility. Additionally, giving status to 
all migrants could deter migrants from entering across unofficial border points because they will know that coming to nation.

\section{DISCUSSION}

In the discussion portion there will be a focus on linking each theme together from the analysis to construct the wholistic perception of immigration detention centres from the lens of NGOs. Immigration detention centres are a representation of the continuous Anti-Black racism that has been a part of Canada's colonial history. Immigration detention centres are detaining thousands of Black and Brown people, and typically not even for immigration violations - just for being in Canada without official documentation or, worse, for being perceived a risk because of one's ethnicity. Detainees are not given fair trials or judgements within their detention reviews. Institutional racism seems to transpire differently depending on the context that Blackness is being read. In Canada, racialized migrants and permanent residences are more susceptible of being placed in detention centres because racialized minorities are monitored and surveillance by the police at a higher rate comparatively to their non-Black counterparts (Tam, 2017). Critical Race theory would identify the racial discrepancy between racialized detainees and White detainees as an illustration of institutional racism. Black and Brown individuals are perceived to be more dangerous, criminal and deviant compared to their White counterparts which places more police surveillance within their communities. When that fear is coupled with mental illnesses there's an increase of police brutality and maltreatment of Black and Brown individuals (Gómez, 2015). Due to the increased surveillance racialized detainees are being detained at a higher rate because when detainees are confronted by immigration officers the detainee has no choice under mandatory detention. Through a critical race perspective, it is 
clearly demonstrated through the treatment of racialized detainees that immigration detention centres can be viewed a racist institution.

The above analysis gives a direct example of racist practices when participants speak about Hussein's experience within detention. Hussein was met with immigration enforcement and tried to resist his deportation and in response he was severely injured by the extreme use of force by immigration officials. The injury that Hussein experienced was not addressed by detention staff and continued to get worse. His loss of hearing then became a setback to Hussein's ability to participate in his own detention reviews which then again, he was denied access to support and resources. This left Hussein in detention for years which then began to affect his mental health and reduced his ability to communicate effectively with his support systems and within his immigration process with officials. These experiences become important to note when discussing immigration detention centre because of the high detention rate of racialized people that occur within these institutions, plus, the increasing acknowledgement of the mental health impacts that detention centres have on detainees (Tam, 2017; Puthoopparambil, Bjerneld, \& Källestål, 2015; Silverman, 2014).

It is difficult to advocate for immigration detainees because Canadians are engulfed with American news around detention and immigration, which renders Canadians to believe that the Canadian government is doing much better than their Southern neighbours and migrants should be thankful of the Canadian government's treatment. Detainees and their supporting communities have taken up action in the form of social resilience; together as a group, as a community, they have formed systems of strength to overcome the barriers and hardships of immigration detention centres (Hall \& Lamont, 2013). Immigration detainees went on multiple hunger strikes to get the attention of administrative officials to make reforms within detention 
centres. Detainees are forming their voices together to implement lists of change that need to be addressed within the facility and they have even placed their own wellbeing at stake to reach these goals. Their hunger strike created a snowball effect of enforcing change, as noted by a participant, a phoneline was developed in response to the hunger strike. The phoneline was used to contact and address the ongoing needs of detainees in maximum and medium security jails, those who were the most marginalized within the detainee community. The phoneline help guide the support systems on how to campaign and advocate for the needs of the detainees. NGOs gathered lawyers, academics, journalists and general volunteers to ensure that the detainees were receiving a holistic support system. NGOs, friends and family members ran an end immigration detention campaigns to produce awareness about immigration detention centres whilst lobbying against the government to implement the list of demands that was constructed with consulting the detainees. Critical race theorist defines these actions as resistance integral for the support of racialized detainees because it changes societies views on how racialized detainees and racialized migrants as a whole should be treated within society. Once the narrative around detainees shift from criminal to "Everyday people" as Participant 2 stated, it diminishes the power of the government to commit cruel acts of punishment towards the detainee population (Wachuku, 2018). Thus, the hunger strike and the phoneline are integral pieces to the migrant detention experience because it was those two mechanisms that linked NGOs and detainees to form stronger connections and support.

NOGs have expressed difficulties with sustaining their support for detainees because they need a variety of a support mechanisms within their network to be beneficial to detainees. It is difficult to maintain enough people within the network to sustain those resources whilst also trying to avoid burnout from the members. NGOs struggled with building enough funds to create 
bail money for detainees who do not have family and friends to support them, as well as, funding to maintain the phoneline, they also lacked accessible transportation due to the remote areas that immigration detainees are placed in and they lack the training to sustain their personal mental health during the process due to the increased contacted with detainees experiences and trying to reduce traumas that were occurring on a daily basis.

\section{CONCLUSION AND RECOMMENDATIONS}

Immigration detention centres act as physical sites of exclusion, meaning the institution themselves do not function in any way to help the detainees integrate into society if their refugee claims are accepted. For example, there are no courses, workshops or skill laboured job for the detainee to partake in while being detained, such as the options prisoners have to take part in while they are incarcerated (Quigley, 2003). Thus, detainees are not perceived as potential actors within society by the Canadian government due to the lack of social inclusion programs provided for detainees. Since the government does not view irregular migrants or detainees as valuable to the nation state, administrative officials place them in immigration detention to with strain their mobility in society. The government is able to enforce indefinite detention on these migrants because society has become complacent if not hostile, due to common discourse around irregular migrants as dangerous and deceitful. Additionally, participants also pointed to a very interesting point that many citizens believe Canada would not do any harm to migrants because of our international status as being a welcoming country. However, these sentiments have left irregular migrants to be punished in correctional facilities for an indefinite amount of time with little accountability.

Under IRPA the government can detain irregular migrants and permanent residences who have lost their status in detention indefinitely as long as they have a detention review every 30 
days. This cycle keeps detainees in jails from months to years amount of time which causes mental and physical health complications such as Hussein's loss of hearing. Being left in jails that range from low to maximum security leave irregular migrants in the crossroads of immigration violation and criminal punishment, known as crimmigration. Even with the running similarities between inmates and immigration detainees, detainees are not given the same rights as inmates since they are not sanctioned to due process. Immigration detainees are detained indefinitely until their status is determined by the Minister Council (Canadian Government Justice Laws Website, 2018). Whereas, prisoner have a right to a trial and are privy to know their estimated release date with options of parole during their time of incarceration. This blurred line increases the mal treatment of detainees within jails because the criminal justice system officials are not aware of who is a detainee and who is an inmate thus, they all receive the same poor treatment.

Critical Race Theorist would support the argument that immigration detention centres were constructed to continue the institutional racism that maintains Whiteness and White supremacy whilst also keeping possession over Indigenous lands. The topic of racism within detention centres can be further researched and explored as this study is not substantial enough to completely address the issue, however, the study does demonstrate that NGOs are viewing their clients experience racism within the system of migrant detention. Additionally, detainees are relating their experiences to feeling like slaves, slavery is an intrinsic experience inflicted on the Black community that has shaped racial relations in modern time and it is argued that slavery is still used in the present day via mass incarceration (read more in Moore, 2017). More in depth studies can be formed around indefinite detention and its relations to racial struggles and ties in 
Canada. This study demonstrated the sentiments of detainees through the lens of NGOs as being mistreated and uncared for by the government due to their race and status.

Furthermore, the NGO and supporting detainee community have built forms of support systems against the will of administrative officials. Many of the NGO representatives have had to find the means to support detainees on their own with minimal guidance which made the process difficult and unsustainable. There needs to be attention by the government to provide financial support to the NGOs that are investing time and resources into the work, that arguably, should be done by the government. Upon release and within detention detainees are left on their own to navigate in a foreign system which creates longer detention periods for the detainee. The government must actively address these issues that detainees and their communities are facing because it is creating large impacts on their physical and mental wellbeing. Likewise, with this information, it is recommended that policy makers and government official listen and adhere to the four lining principles outlined by the NGOs.

The first one is implementing a 90-day limit on indefinite sentencing, this should be a main priority in the government because detaining people indefinitely is inhumane and cruel punishment and it is currently the most severe form of punishment that the Canadian government has. Secondly, with the expansions of the immigration holding centres there needs to be implicit intent by the government to remove immigration detainees from maximum and medium provincial jails into low security grade holding centre. Although NGOs would like to see the abolishment of immigration detention centres there is space to in their movements to at least allow for the transfer of detainees from maximum and medium security jails to low security holding centres. To detain immigration detainees within jail imposes criminality on the detainee without granting them legal rights of the criminal justice system. The expansion of immigration 
detention centres ties into the third recommendation which is ensuring the facilities are built in easily accessible locations where detainees can receive support from family, friends and professionals. Lastly, the government should not be stripping permanent residences of their immigration status. To receive permanent residence status is difficult and costly and should be the physical representation of an individual's guarantee to receive their citizenship. These four changes would grant detainees the ability to mobilize themselves to make their current conditions better. Immigration detainees are one of the most marginalized communities in Canada and the government needs to start implementing changes to support this community in attaining better lives. 


\section{APPENDIX}

\section{Consent form}

Ryerson University

Consent Agreement

You are being invited to participate in a research study. Please read this consent form so that you understand what your participation will involve. Before you consent to participate, please ask any questions to be sure you understand what your participation will involve.

\section{EVALUATING ONTARIO IMMIGRATION DETENTION CENTRES THROUGH THE LENS OF NON-GOVERNMENTAL ORGANIZATIONS}

This research study is being conducted by Sharyne Williams with support of my research supervisor Dr. Graham Hudson from the Immigration and Settlement Studies MA at Ryerson University.

If you have any questions or concerns about the research, please feel free to contact Sharyne Williams at sharyne.williams@ ryerson.ca.

\section{PURPOSE OF THE STUDY:}

The study is for a Master Thesis project that is focusing on collecting the stories of stakeholders within detention centres to see the how the behavioural practices of government administrative official and policies effect the stakeholders experience. There will be 6 participants taking part in the study who are from 3 identified groups, a former immigration detainee that was held in an Ontario immigration detention centre, an immigration lawyer who has supported or defended a detainee or a Non-Governmental Organization who has advocated or supported detainees within Ontario. The data will be used for the purpose of a Master Research Paper.

\section{WHAT YOU WILL BE ASKED TO DO:}

If you volunteered to participate in this study, you will be asked to do the following things:

Once you contact Sharyne Williams the time, date and location will be determined based on your discretion. The interview will take an estimated time of 60 minutes in length. The interview will contain open and closed ended questions for the participant to answer such as, how long have you been advocating for detainees in detention? What experiences or stories have you heard from detainees that shape your views on immigration detention centres? What are the challenges of advocating for detainees? The data collected will be used for the purpose of a Master Research Paper, which will be made available on the Ryerson Immigration and Settlement website. The participant will receive a link to the website via email once the final Master Research Paper has been posted.

\section{POTENTIAL BENEFITS}

I cannot guarantee that you will receive any benefits from participating in this study. 


\section{THE POTENTIAL RISKS TO YOU AS A PARTICIPANT}

There are minimal risks for you to participate in this study. You are being asked to come and speak about your experience which may bring up emotional discomfort. If the you feel uncomfortable at any moment, you are able to skip any questions or stop your participation, either temporarily or permanently from the study. I, Sharyne Williams, will ensure that any identifying information will be withheld from the final paper.

\section{CONFIDENTIALITY}

Identifying information gained from the you will be removed from the results, you will be given a number to identify your interview on files, the interview number will only be known by Sharyne Williams, this is to keep names separate from interviews. If names or identifying information is mentioned within the interview, the quote will not be used or where applicable, the name will be marked out of the final results. To ensure confidentiality you can be given a fake name that only I, Sharyne Williams, will know who the names belong to, this way there can be no traces back to you as the participant. If a fake name is not chosen by you, then one will be administered by myself to be used for the final paper.

Audio recordings of the interviews (except in cases where you request that no recordings be made, which then written transcriptions will happen throughout the interview) will be made into transcriptions into a locked google drive. Audio recording and transcriptions will be held on a google drive where only Sharyne Williams and Dr. Graham Hudson will have access to the raw data. Participants have a right to review their recordings and the transcripts which can be arranged with Sharyne Williams to meet up for review, since the data cannot be emailed or transferred electronically. The files are used for a Masters Research Paper and will be destroyed once the paper is complete and handed in on September $1^{\text {st, }}, 2019$.

As the researcher I do have to follow the protocol of 'Duty to Report', this means that I have a legal obligation to potentially break confidentiality in five cases: 1) if you intend to harm yourself, 2) if you intend to harm others, 3) if there is reasonable suspicion a child up to the age of 16 is at risk of neglect or abuse, 4) if my files are subpoenaed by courts, and 5) if a regulated health professional has engaged in inappropriate sexual behaviour towards you.

\section{COMPENSATION FOR INJURY}

By agreeing to participate in this research, you are not giving up or waiving any legal right in the event that you are harmed during the research.

\section{VOLUNTARY PARTICIPATION AND WITHDRAWAL}

Participation in this study is completely voluntary. You can choose whether to be in this study or not. If any question makes you uncomfortable, you can skip that question. You may stop participating at any time and you will still be given the incentives and reimbursements described above. If you choose to stop participating, you may also choose to not have your data included in the study. Your choice of whether or not to participate will not influence your future relations with Ryerson University or Sharyne Williams or Dr. Graham Hudson involved in the research.

\section{DATA STORAGE AND DISSEMINATION}


Audio recordings will be deleted once they have been transcribed into a locked google drive. The transcriptions will be deleted once the Master Research Paper has been completed and submitted on September $1^{\text {st }} 2019$. The data will only be used for the purpose of the Master Research Paper and will not be shared with anyone. You will have access to the final product of the Research Paper through the Immigration and Settlement Studies program website (https://www.ryerson.ca/graduate/programs/immigration/mrp/).

\title{
QUESTIONS ABOUT THE STUDY
}

If you have any questions about the research now, please ask. If you have questions later about the research, you may contact: Sharyne Williams at sharyne.williams@ryerson.ca.

This study has been reviewed by the Ryerson University Research Ethics Board. If you have questions regarding your rights as a participant in this study, please contact:

\author{
Research Ethics Board \\ c/o Office of the Vice President, Research and Innovation \\ Ryerson University \\ 350 Victoria Street \\ Toronto, ON M5B 2K3 \\ 416-979-5042 \\ rebchair@ryerson.ca
}

\section{CONFIRMATION OF AGREEMENT}

Your signature below indicates that you have read the information in this agreement and have had a chance to ask any questions you have about the study. Your signature also indicates that you agree to participate in the study and have been told that you can change your mind and withdraw your consent to participate at any time. You have been given a copy of this agreement. You have been told that by signing this consent agreement you are not giving up any of your legal rights.

Name of Participant (please print)

Signature of Participant

Date

I agree to be audio-recorded for the purposes of this study. I understand how these recordings will be stored and destroyed. 


\section{REFERENCES}

Albrecht, E., \& Plewa, M. P. (2015). International recognition of environmental refugees. Environmental Policy and Law, 45(2), 78-84. Retrieved from http://ezproxy.lib.ryerson.ca/login?url=https://search-proquestcom.ezproxy.lib.ryerson.ca/docview/1693883063 ?accountid=13631

Althaus, S. L., \& Largio, D. M. (2004). When Osama became Saddam: Origins and consequences of the change in America's public enemy\# 1. PS: Political Science \& Politics, 37(4), 795-799.

Amin-Khan, T. (2015). Security and its impact on immigrants and refugees. Immigrant Experiences in North America: Understanding Settlement and Integration in North America, 118-143.

Annas, G. J. (1995). Hunger strikes. BMJ, 311, p. 1114-1115. Retrieved from https://www.ncbi.nlm.nih.gov/pmc/articles/PMC2551051/pdf/bmj00616-0008.pdf

Arat-Koç, S. (2005). The disciplinary boundaries of Canadian identity after September 11: Civilizational identity, multiculturalism, and the challenge of anti-imperialist feminism. Social Justice, 32(4), 32.

Blumstein, A. (2015). Racial disproportionality in prison. In Race and social problems (pp. 187193). Springer, New York, NY.

Bosworth, M. (2018). Alternatives to Immigration Detention: A Literature Review. Retrieved From https://arts.monash.edu/_data/assets/pdf_file/0004/1627897/ALTERNATIVESTODETE NTIONReview.pdf

Bosworth, M., \& Turnbull, S. (2014). Immigration detention, punishment, and the criminalization of migration. The Routledge handbook on crime and international migration, 91-106.

Canadian Border Service Agency [CBSA]. (2018). Annual Detention Statistics 2012-2018. Government of Canada. Retrieved from: https://cbsa-asfc.gc.ca/securitysecurite/detent/stat-2012-2018-eng.html

Canadian Council for Refugees [CCR]. (n.d). Detention of Children. Canadian Council for Refugees. Retrieved from https://ccrweb.ca/en/detention-children

Canadian Government Justice Laws Website. (2018). Immigration and Refugee Protection Act (2001). Retrieved from https://laws-lois.justice.gc.ca/eng/acts/I-2.5/FullText.html 
Canadian Press Newswire. (July 7, 2019). Five things to know about Canadian immigration detention centres. Government of Canada. Retrieved from https://www.informedia.gc.ca/cic/en/2019/07/07/221002676

Cole, G. (2017). Beyond labelling: Rethinking the role and value of the refugee 'Label' through Semiotics. Journal of Refugee Studies, 31(1), 1-21.

Coligado, M. A. (2018). In Defence of Invisiblized Noncitizens: Seeking Justice in the Canadian Immigration Detention System (Doctoral dissertation, Carleton University).

Conlon, D. (2013). Hungering for freedom: Asylum seekers' hunger strikes-Rethinking resistance as counter-conduct. Carceral spaces: Mobility and agency in imprisonment and migrant detention, 133-148.

Crenshaw, K. (1991). Mapping the margins: Intersectionality, identity politics, and violence against women of color. Stanford law review, 1241-1299.

Creswell, W., \& Poth N. C. (2018). Qualitative Inquiry and Research Design:

Choosing Among Five approaches. Thousand Oaks, CA: Sage. (pp. 65-110).

Cretney, R., 2014. Resilience for Whom? Emerging Critical Geographies of Socio-ecological Resilience. Geography Compass, 8(9), 627-640.

Crichlow, W. (2015). Critical Race Theory: A Strategy for Framing Discussions Around Social Justice and Democratic Education. Higher Education in Transformation Conference, Dublin, Ireland, 2015, 187-201.

Dawson, G. (2018). Why Justin Trudeau is not the leader many believe he is.

De Goede, M. (2008). Beyond risk: Premediation and the post-9/11 security imagination. Security dialogue, 39(2-3), 155-176.

Delgado, R., \& Stefancic, J. (2017). Critical race theory: An introduction. NYU Press.

Dhamoon, R., \& Abu-Laban, Y. (2009). Dangerous (internal) foreigners and nation-building: The case of Canada. International political science review, 30(2), 163-183.

Doane, A. (2017). Beyond Color-blindness:(Re) Theorizing Racial Ideology. Sociological Perspectives, 60(5), 975-991.

End Immigration Detention Network [EIDN]. (n.d). About Us. End Immigration Detention Network. Retrieved from https://endimmigrationdetention.com/about/

End Immigration Detention Network [EIDN]. (2014) Indefinite, Arbitrary and unfair: the truth about 
immigration detention in Canada. End Immigration Detention Network. Retrieved from 140714_DR_Report_FINAL (web).pdf

Evans, P. B. (2018). Dependent development: The alliance of multinational, state, and local capital in Brazil. Princeton University Press.

Figueroa, A. M. (2017). Speech or silence: Undocumented Students' decisions to disclose or disguise their citizenship status in school. American Educational Research Journal, 54(3), 485-523. doi: 10.3102/0002831217693937

Gauvreau, C., \& Williams, G. (2002). Detention in Canada: are we on the slippery slope?. Refuge: Canada's Journal on Refugees, 20(3), 68-70.

Glaser, J. (2015). Suspect race: Causes and consequences of racial profiling. Oxford University Press, USA.

Global Detention Project. (2018). Immigration detention in Canada: Important reforms, ongoing concerns. Global Detention Project. Retrieved from https://www.globaldetentionproject.org/countries/americas/canada

Goldring, L., Berinstein, C., \& Bernhard, J. K. (2009). Institutionalizing precarious migratory status in Canada. Citizenship studies, 13(3), 239-265.

Gómez, J. (2015). Microaggressions and the enduring mental health disparity: Black Americans at risk for institutional betrayal. Journal of Black Psychology, 4l(2), 121-143.

Hall, P. A., \& Lamont, M. (Eds.). (2013). Social resilience in the neoliberal era. Cambridge University Press.

Hari, A. (2014). Temporariness, rights, and citizenship: The latest chapter in Canada's Exclusionary migration and refugee history. Refuge, 30(2), 35-44.

Hudson, G., Nakache, D., \& Atak, I. (2018). Editorial. International Journal of Migration and Border Studies, 4(4), 281-286

Huot, S., Bobadilla, A., Bailliard, A., \& Laliberte Rudman, D. (2016). Constructing undesirables: A critical discourse analysis of 'othering' within the Protecting Canada's Immigration System Act. International Migration, 54(2), 131-143.

International Human Rights Program, Amnesty International, Justice for children and youth, Canadian Association of Refugee Lawyers, Canadian Civil Liberties Association \& Refugee Law Office of Legal Aid Ontario. (2018). Rights Violations Associated with Canada's Treatment of Vulnerable Persons in Immigration Detention. Universal Period Review. 1-57 
James, C. E. (2011). Multicultural education in a color-blind society. Intercultural and Multicultural Education: Enhancing global interconnectedness, 39, 191-210.

Joseph, J. (2013). Resilience as embedded neoliberalism: a governmentality approach. Resilience, 1(1), 38-52.

Kallen, E. (1982). Multiculturalism: Ideology, policy and reality. Journal of Canadian Studies, 17(1), 51-63.

Kaushik, V., \& Drolet, J. (2018). Settlement and Integration Needs of Skilled Immigrants in Canada. Social Sciences, 7(5), 76.

Kellezi, B., \& Bosworth, M. (2016). Mental health, suicidal thoughts and self-harm inside Immigration detention. SSRN Electronic Journal. doi: 10.2139/ssrn.2867358

Keung, N. (Nov. 9, 2018). Immigration detainee sues feds for \$50 million, alleging he suffered a mental breakdown and was given electric shock treatment. TheStar. Retrieved from https://www.thestar.com/news/gta/2018/11/09/immigration-detainee-sues-feds-for-50million-alleging-he-suffered-a-mental-breakdown-and-was-given-electric-shocktreatment.html

Khoday, A. (2016). Resisting Criminal Organizations: Reconceptualizing the "Political" in International Refugee Law. McGill Law Journal/Revue de droit de McGill, 61(3), 461509.

Kolber, J. (2017). Having it both ways: White denial of racial salience while claiming oppression. Sociology Compass, 11(2), 1-9. doi 10.1111/soc4.12448

Lacroix, M. (2004). Canadian refugee policy and the social construction of the refugee claimant subjectivity: Understanding refugeeness. Journal of Refugee Studies, 17(2), 147-166.

Lee, R. M. (2005). Resilience against discrimination: ethnic identity and other-group orientation as protective factors for Korean Americans. Journal of Counseling Psychology, 52(1), 36.

Lester, T. W., \& Nguyen, M. T. (2016). The economic integration of immigrants and regional Resilience. Journal of Urban Affairs, 38(1), 42-60.

Levy, M. A. (1995). Is the environment a national security issue?. International security, 20(2), $35-62$.

Logan, E. (2014). Barack Obama, the new politics of race, and classed constructions of racial blackness. The Sociological Quarterly, 55(4), 653-682. doi 10.1111/tsq.12071

Luchies, T. (2015). Towards an insurrectionary Power/Knowledge: Movement-relevance, antioppression, prefiguration. Social Movement Studies, 14(5), 523-538.

doi:10.1080/14742837.2014.998643 
Luthar, S. S. (2015). Resilience in development: A synthesis of research across five decades. Developmental Psychopathology: Volume Three: Risk, Disorder, and Adaptation, 739-795.

Macklin, A. (1998). Truth and consequences: Credibility determination in the refugee context (pp. 134-140). International Association of Refugee Law Judges.

MacKinnon, D., \& Derickson, K. D. (2013). From resilience to resourcefulness: A critique of resilience policy and activism. Progress in Human Geography, 37(2), 253-270.

Magis, K. (2010). Community resilience: An indicator of social sustainability. Society and Natural Resources, 23(5), 401-416.

Massa, G. (Jul 2019). Advocates concerned over reports of random ID checks from immigration officers in Toronto. CityNews. Retrieved from https://toronto.citynews.ca/2019/07/12/advocates-concerned-over-reports-of-random-idchecks-from-immigration-officers-in-toronto/

McLeod, S. (2007). Maslow's hierarchy of needs. Simply Psychology, 1.

Mekawi, Y., Bresin, K., \& Hunter, C. (2017). Who is more likely to "Not see race"? Individual differences in racial colorblindness. Race Soc Probl, 9, 207-217. doi 10.1007/s12552017-9211-3.

Michail, D. (2013). Social development and transnational households: resilience and motivation for Albanian immigrants in Greece in the era of economic crisis. Southeast European and Black Sea Studies, 13(2), 265-279.

Moffette, D., \& Aksin, N. (2018). Fighting human smuggling or criminalizing refugees? Regimes of justification in and around $\mathrm{r} v$ Appulonoppa. Canadian Journal of Law and Society, 33(1), 21-39. doi:10.1017/cls.2018.2.

Moore, R. (2017). The new Jim Crow: Mass incarceration in the age of colourblindness. Macat Library.

Mountz, A., Coddington, K., Catania, R. T., \& Loyd, J. M. (2013). Conceptualizing detention: Mobility, containment, bordering, and exclusion. Progress in Human Geography, 37(4), 522-541.

Murray Nettles, S., Mucherah, W., \& Jones, D. S. (2000). Understanding resilience: The role of social resources. Journal of Education for Students Placed at Risk (JESPAR), 5(1-2), 4760 .

Pastor, M., \& Mollenkopf, J. (2012). Struggling over strangers or receiving with resilience? The 
metropolitics of immigrant incorporation. Urban and regional policy and its effects, 4, 90089-1291.

Paternoster, R. (2018). Perceptual deterrence theory. In Deterrence, Choice, and Crime, Volume 23 (pp. 91-116). Routledge.

Plodinec, M. J. (2009). Definitions of Resilience: An Analysis. Community and Regional Resilience Institute. National Security Directorate.

Potter, H. (2015). Intersectionality and criminology: Disrupting and revolutionizing studies of crime. New York: Routledge

Puthoopparambil, S. J., Bjerneld, M., \& Källestål, C. (2015). Quality of life among immigrants in Swedish immigration detention centres: a cross-sectional questionnaire study. Global Health Action, 8(1), 1-10.

Quigley, W. P. (2003). Prison Work, Wages, and Catholic Social Thought: Justice Demands Decent Work for Decent Wages, Even for Prisoners. Santa Clara L. Rev., 44, 1159-1178.

Reddekopp, L. (Nov. 10, 2018). Immigration detainee seeks 65\$M in lawsuit against Ottawa for violating rights. $C B C$ News. Retrieved from https://www.cbc.ca/news/canada/toronto/man-lawsuit-immigration-detention-federalgovernment-1.4899770

Richeson, J. A., \& Nussbaum, R. J. (2004). The impact of multiculturalism versus colorblindness on racial bias. Journal of Experimental Social Psychology, 40(3), 417-423.

Selod, S. (2015). Citizenship denied: The racialization of Muslim American men and women post-9/11. Critical Sociology, 41(1), 77-95.

Shalev, S. (2017). Solitary confinement as a prison health issue.

Sheppard, B. (2018). Prison strike targets slave labour. Green Left Weekly, (1195), 15.

Silverman, S. (2014). In the wake of irregular arrivals: Changes to the Canadian immigration detention system. Refuge, 30(2), 27-34

Silverman, S., \& Molnar, P. (2016). Everyday injustices: barriers to access to justice for immigration detainees in Canada. Refugee Survey Quarterly, 35(1), 109-127.

Supreme Court of Canada (SCC). (2007). Charkaoui v. Canada (Citizenship and Immigration). $R$. v.Comeau - SCC Cases (Lexum). Retrieved from scccsc.lexum.com/scc-csc/scc-csc/en/item/2345/index.do.

Tam, L.(2017). Agitation and sudden death: Containing Black detainees affect. American Quarterly, 6992), 339-345. doi: https://doi.org/10.1353/aq.2017.0030 
Thomas, R. (2013). Resilience and housing choices among Filipino immigrants in Toronto. International Journal of Housing Policy, 13(4), 408-432.

UNHCR. (1951). Convention and protocol: Relating to the status of refugees. The UN Refugee Agency. Retrieved from https://www.unhcr.org/3b66c2aa10

Van den Hoonaard, D. K. (2012). Qualitative research in action: A Canadian primer. Don Mills, ON: Oxford University Press Canada

Wachuku, V. C. (2018). Understanding the Role of Advocacy Coalitions in Canada's Immigration Detention Policy Subsystem. Retrieved from https://www.ippapublicpolicy.org/file/paper/5b1e1a8898aec.pdf

Wallace, R. (2018). Contextualizing the crisis: The framing of Syrian refugees in Canadian print media. Canadian Journal of Political Science, 51(2), 207-231. doi:10.1017/S0008423917001482

Zetter, R. (2007). More labels, fewer refugees: Remaking the refugee label in an era of globalization. Journal of refugee studies, 20(2), 172-192. 